\title{
Research Paper \\ Comparison of Psychosocial Development in 4 to 6 Year-old Male and Female Children Attending Kindergarten and those not Attending it in the Deprived Areas of Qom City during the Academic Year 2013-2014
}

\author{
Mahdi Ghelichi ${ }^{1}$, Alireza Karimpour Vazifehkhorani ${ }^{2}$, Siyamak Tahmasebi Garmtani ${ }^{* 3}$ \\ 1. Ph.D. Student of Educational Psychology, Rudehen Branch, Islamic Azad University, Rudehen, Iran \\ 2. M.A. In Clinical Psychology, Faculty of Psychology and Educational Sciences, Tabriz University, Iran \\ 3. Assistant Professor, Department of Preschool Education, Faculty of Educational Sciences and Social Welfare, University of Social \\ Welfare and Rehabilitation Sciences, Tehran, Iran
}

Citation: Ghelichi M, Karimpour Vazifehkhorani A, Tahmasebi Garmtani S. Comparison of psychosocial development in 4 to 6 year-old male and female children attending kindergarten and those not attending it in the deprived areas of qom city during the academic year $2013-2014$. Quarterly Journal of Child Mental Health. 2020; 7(1): 141-154.

http://dx.doi.org/10.29252/jcmh.7.1.13

\section{A R T I C L E I N F O}

\section{Keywords:}

Kindergarten, behavioral problems, deprived areas of Qom city, social development, 4 to 6 year-old children

Received: 28 May 2018 Accepted: 3 Sep 2018 Available: 20 Jun 2020

\section{A B S T R A C T}

Background and Purpose: The very beginning years of child's life are critically important. All educators have emphasized the importance of the early childhood in the life-long development, because, on one side, learning and development are of higher speed during this period and, on the other side, the experiences of this period form the basis of learning in the next stages of life. Accordingly, this study aimed to compare the psychosocial development of 4 to 6-year-old children attending the kindergarten and those not attending it in the deprived areas of Qom city.

Method: In this casual-comparative research study, eighty 4 to 6-year-old children attending kindergarten and the same number of children not attending it were selected from the deprived areas of Qom city by clustering sampling method and matching. The tools included Child Behavior Checklist (Achenbach\& Edelbrock, 1983) and Vineland Adaptive Behavior Scales (Sparrow \& Cicchetti, 1989). Data were analyzed by analysis of variance and independent samples t- test.

Results: Findings showed that social development in children attending kindergarten was higher than those not attending it; and this difference was statistically significant at $\mathrm{p}<0.01$. Besides, among the components of behavioral problems, isolation and social problems were more common in children not attending the kindergarten compare to the other group, at a significance level of $\mathrm{p}<0.05$. Furthermore, the rate of aggressive behaviors in boys attending the kindergarten was higher than the boys not attending the kindergarten and the girls; and this difference was significant at $\mathrm{p}<0.05$.

Conclusion: Because of receiving different trainings and gaining new skills, children attending the kindergarten show higher adjustment and social development and experience lower academic stress compared to those not attending the kindergarten.

\footnotetext{
* Corresponding author: Siyamak Tahmasebi Garmtani, Assistant Professor, Department of Preschool Education, Faculty of Educational Sciences and Social Welfare, University of Social Welfare and Rehabilitation Sciences, Tehran, Iran.

E-mail addresses: Siyamak.tahmasebi@gmail.com
} 


\section{مقايسه تحول روانى ـ اجتماعى كود كان دختر و هـر ع تا ح ساله مهد كود ككرو و غير مهد كودكرو

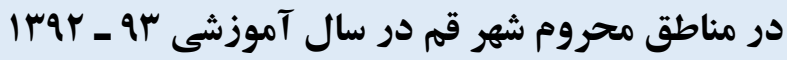

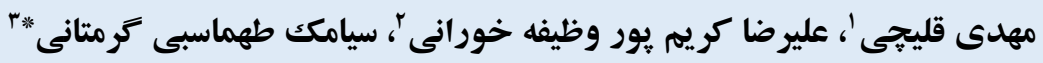

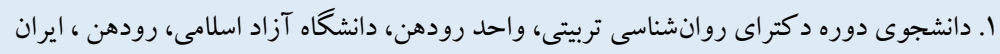

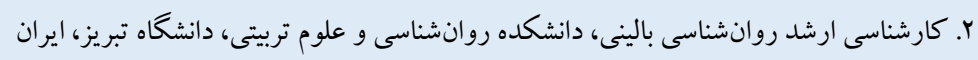

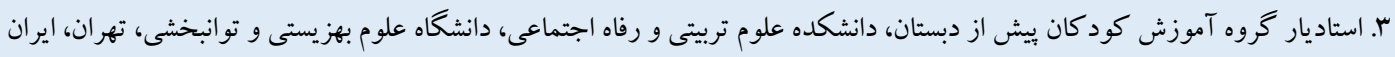

زمينه و هدف: سالهاى اوليه زندگى كود كك از حساسيت و اهميت خاصى برخوردار است و تمامى كارشناسان و مربيان تعليم و تربيت به

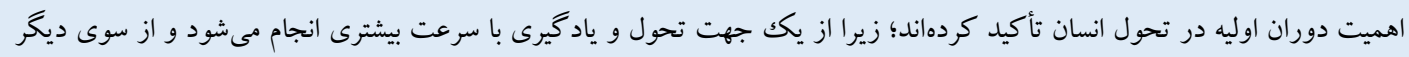

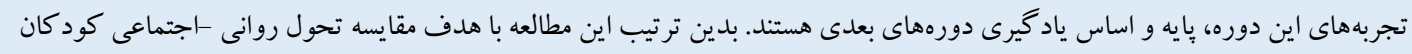

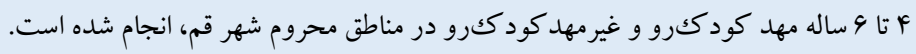

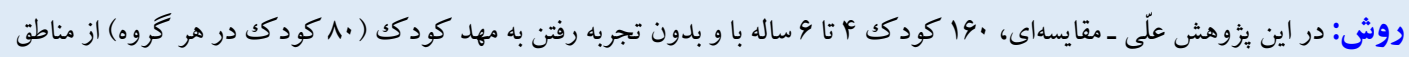

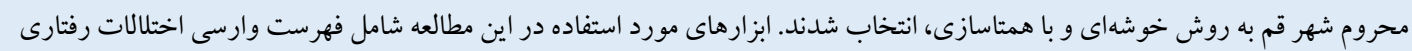

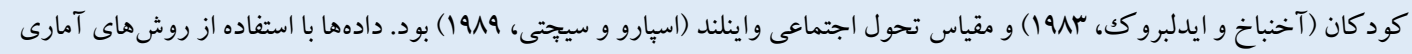
تحليل واريانس و آزمون تى مستقل تحليل شدند.

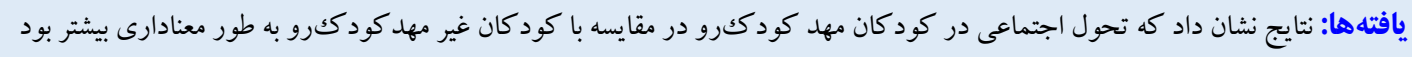

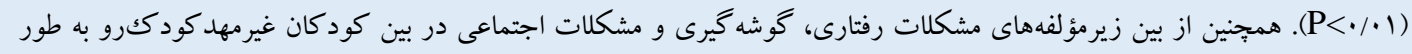

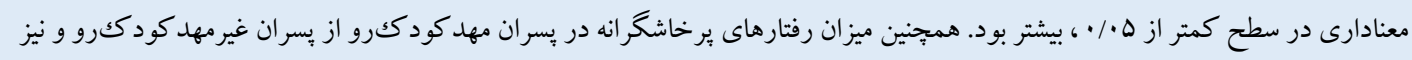

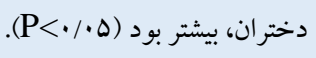


همجنين گزارش شــده اسـت كود كانى كه در مهد كو دككها شـر كت

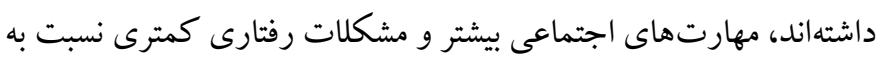
همسالان خود كه در خانه بودهاند، نشان دادهاند (A).

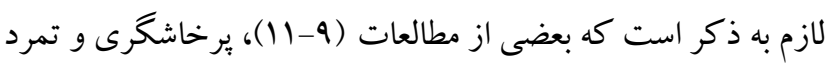

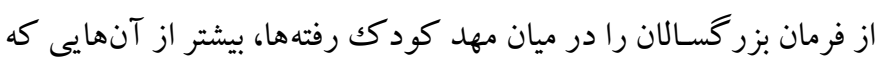

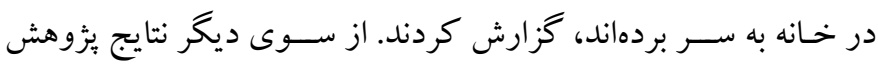

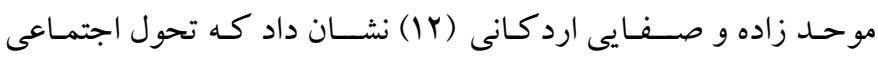

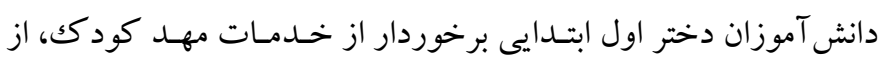

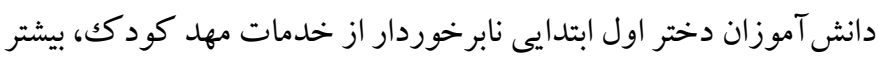

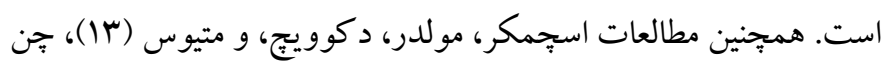

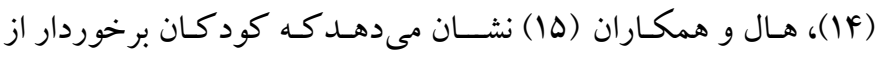
خـدمات مهد كودكك نســبت به كود كان نابرخوردار از اين خدمات، از تحول اجتمـاعى بـالـاترى برخوردارنـد و مشـكلات اجتماعى كمترى را

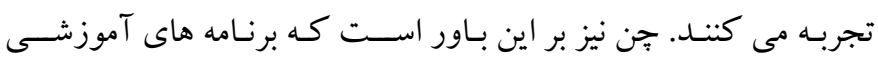

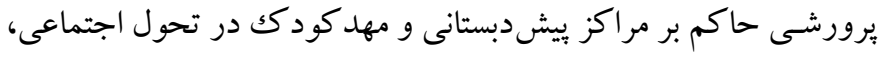

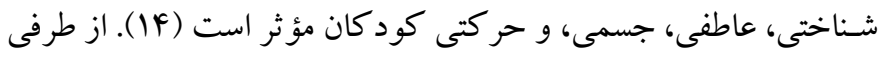

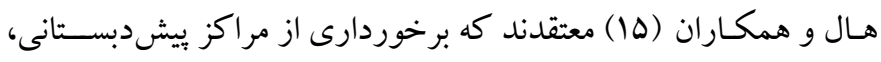

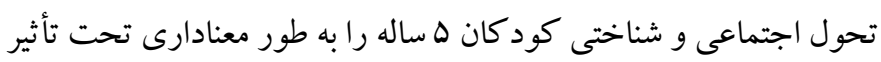

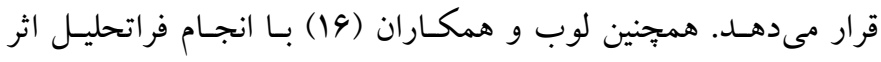
مــداخلـات آموزشــى اوليهه بر تحول شـــــاختى و اجتماعى به اين نتيجه

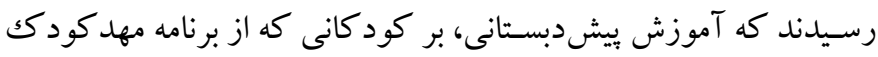

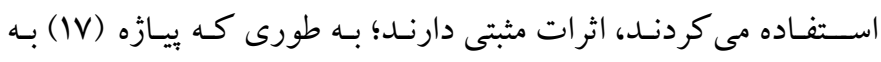

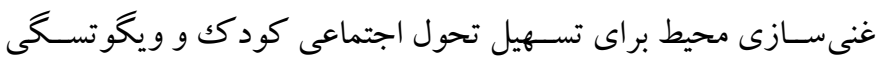

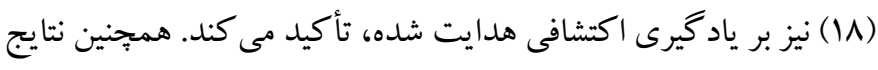

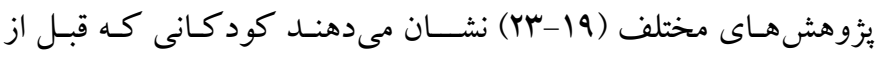

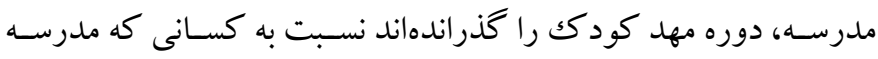

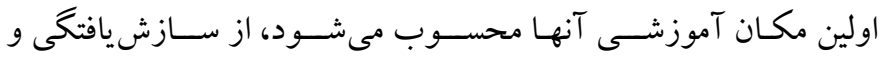

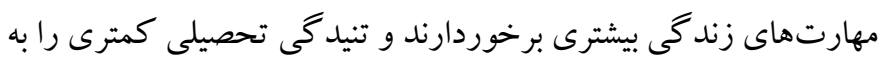

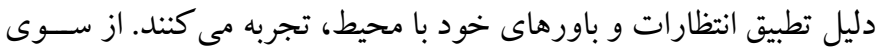

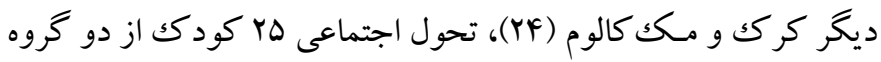
مهد كودككرو و كود كانى كه در خانه مراقبت مىشـوند را با استفاده از
مقلدمه

بخش مهمى از تحول مغز انسان در طى دوره كو تاهى رخ خواهد داد كه

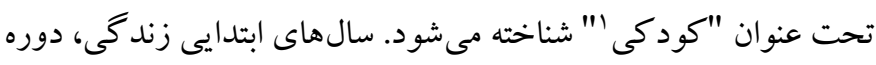

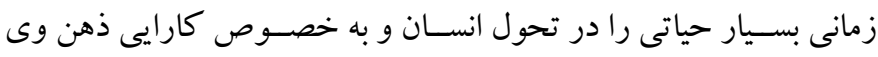

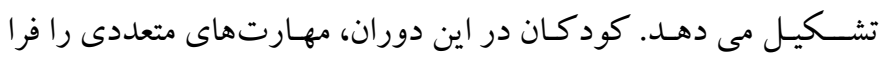

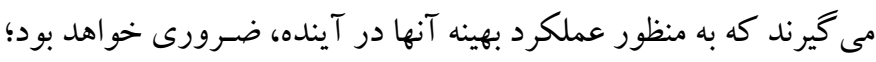
به عبارت ديخر، بايههاى معمارى مغز و متعاقب آن يتانسـيل تحول مادرام العمر، در سـالهاى اوليه كود كك در طى فرايندى قرار مى گيرد كه كاملاً نسبت به نفوذ و ياد گيرهاى بيرونى، حساس است. تجربيات اوليه در خانه و سـاير تنظيمـات مراقبت در جامعه با زنها در ارتباط بوده و ماهيت در

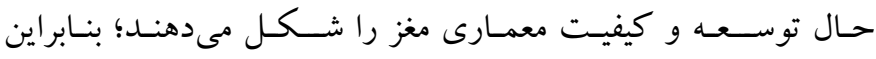

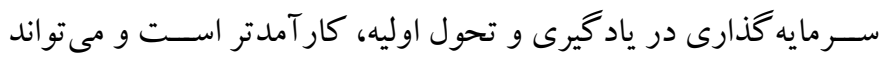

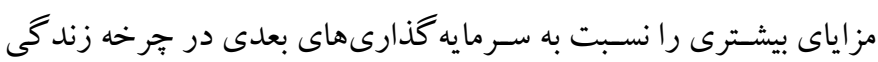

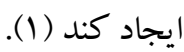

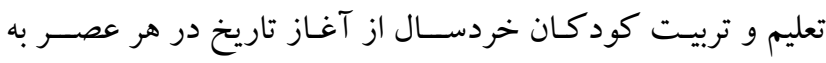
شكل هاى مختلف و در بين هر قوم به نوعى مورد توجه خاص قرار گرفته

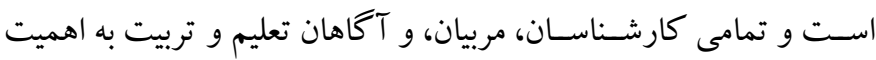

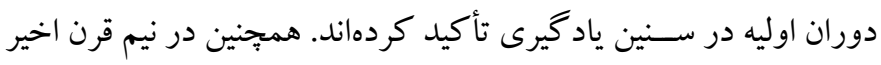

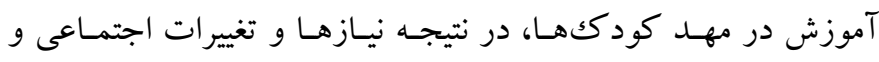
اقتصادى ضرورت بيدا كرده است و غنى بودن محيط در دوران مذكور

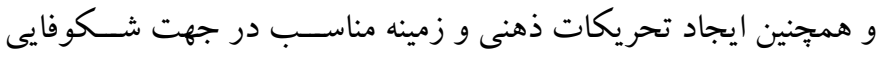

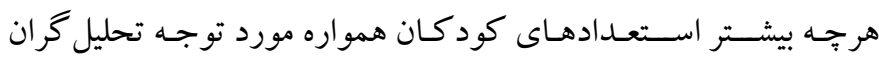

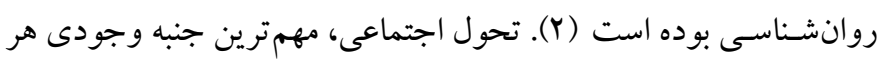

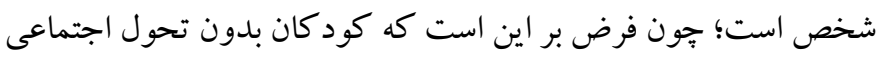

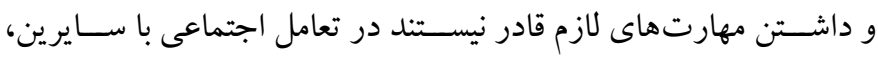

$$
\text { وظايف خود را انجام دهند (r). }
$$

يزووهش هـا نشــان دادهانــ كه مهل كود ككها، نقش مهمى در تحول

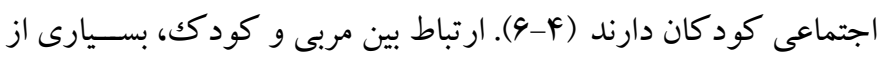
خواص و عملكرد روابط مثبـت و نزديـكك بين كود كك و والـدين را دارا اسـت. به اين ترتيب يشتيبانى كردن از روابط با كيفيت بالا، يا ارزش قائل

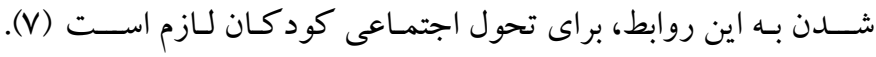


شـرم و خجالت و سـطح دقت و توجه بيشـتر هسـتند كه احتمالاً به دليل

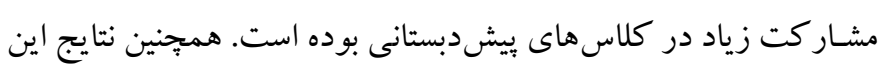

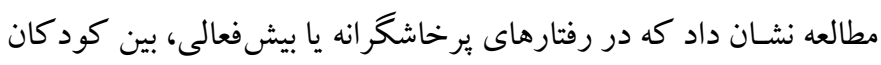
مهدكودككرو و ساير كود كان، تفاوت معنادارى وجود ندارد.

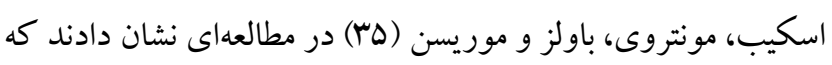

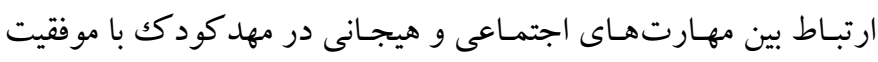

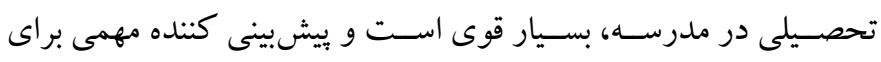
عملكرد تحصسيلى كود كان در كلاس اول نسـبت به سـابقه خانو اد گكى و

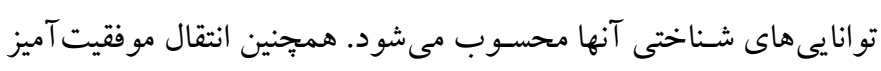

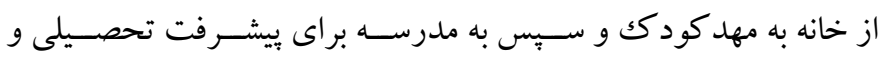

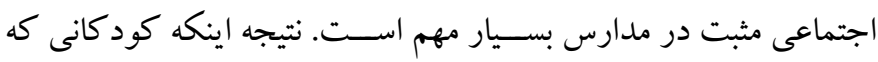

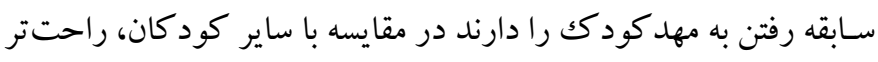
به مدرسـه وارد مى شـوند و عملكرد اجتماعى بالاترى را نشــان مى دهند.

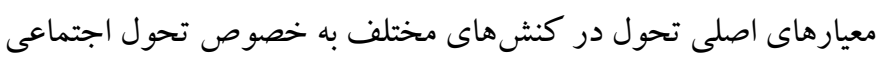

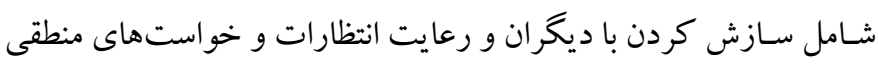

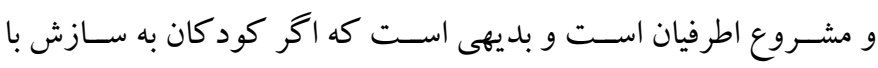

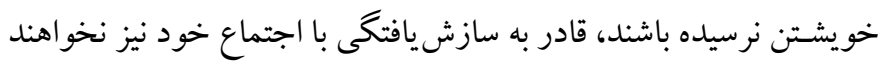

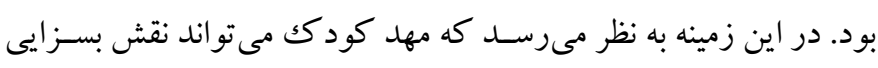

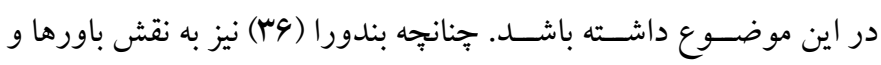

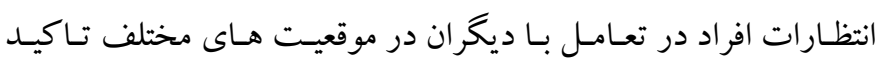
مى كند. در اين راستا، كود كانى كه در حال ورود به جامعه مدرن هستند

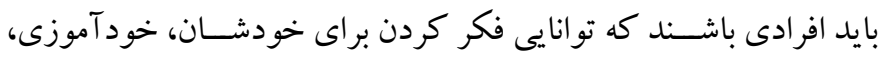

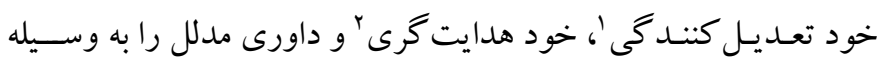
كسب مهارت هاى زندگى و گسترش قلمرو ارتباطى، داشته باشند (rV).

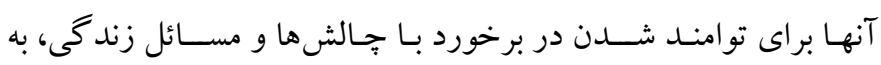

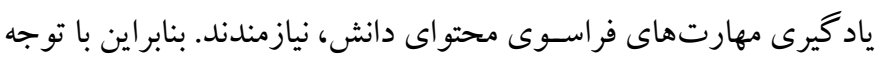

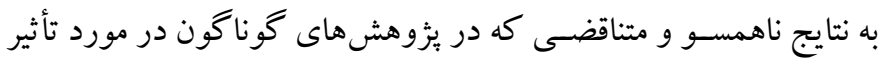

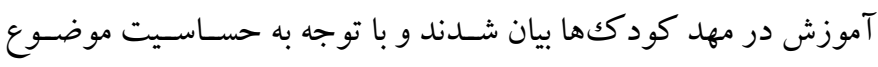

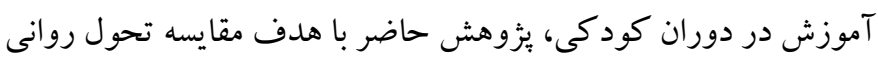

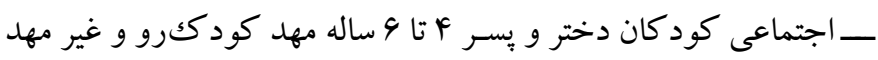
2. Self-directing
مقياس واينلند مورد بر رسى قرار دادند و به اين نتيجه رسيدند كه تفاوتى

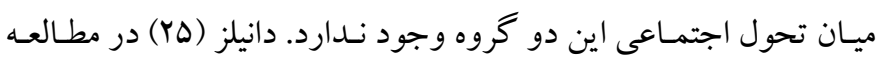

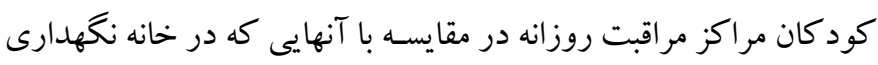
مى شـدند، نشـان داد كه كود كان سـاكن در مراكز مراقبت روزانه، تعامل

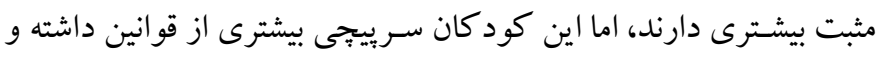

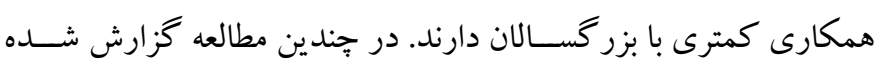

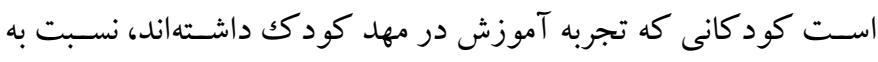

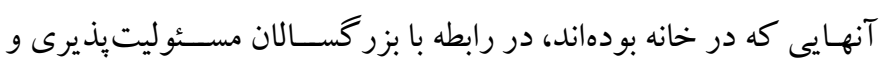

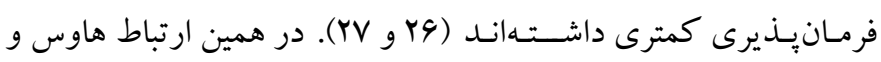

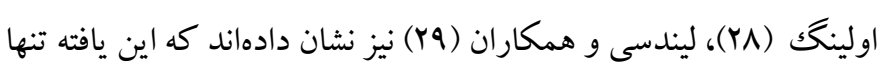

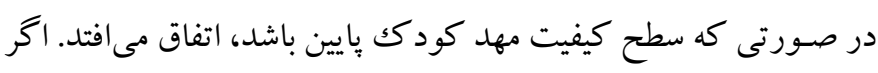

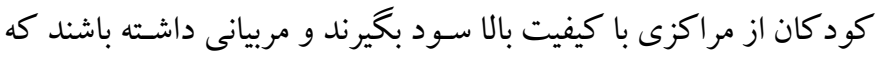

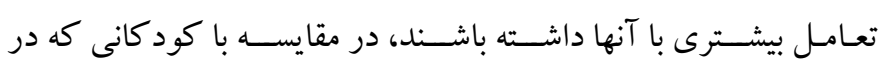

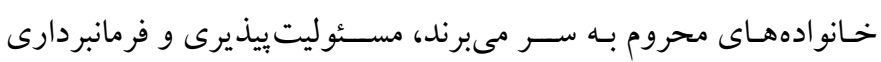
بيشترى را نشان مى دهند.

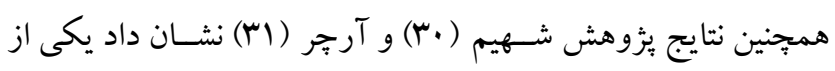

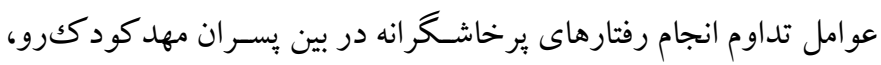
كسب محبوبيت و توجه از طرف همسـالان اسـت. يوشيكاوا و همكاران

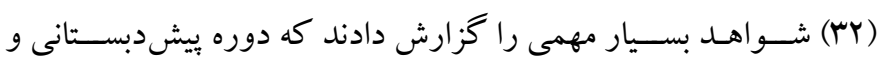

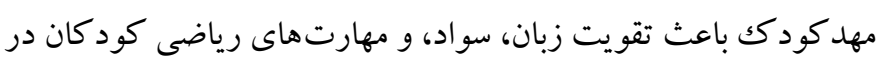

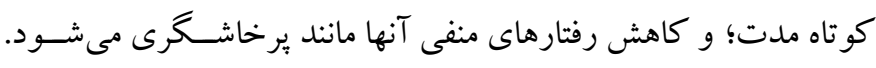

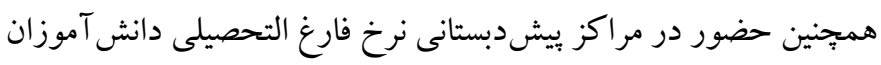

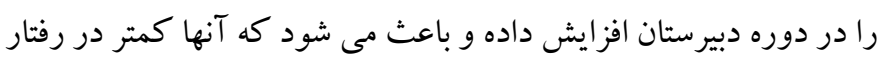

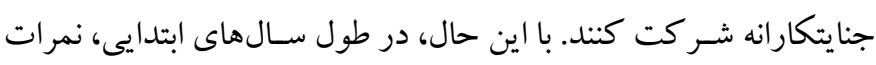

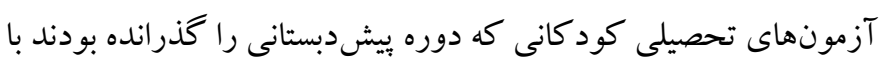

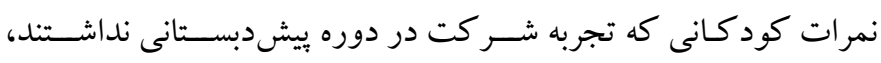
نزديك بود.

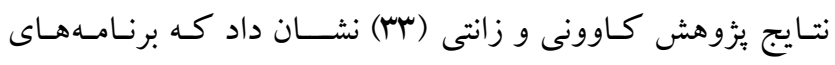

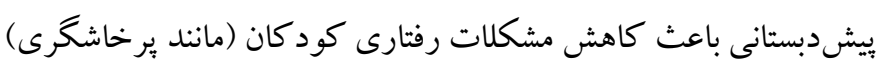

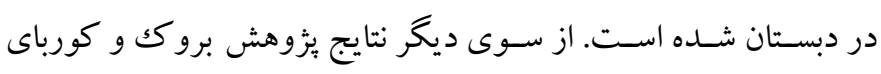

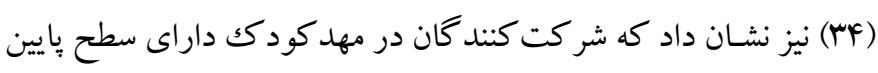

1. Self-modulation 
حيطه ارتباطى شــامل زيربخش هاى دريافتى، بيانى، و نوشـتارى اسـت؛

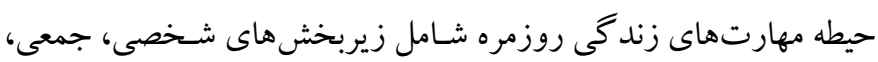

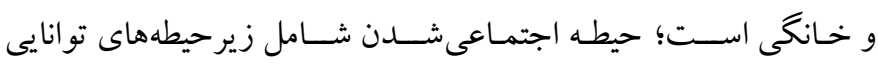
سـازش يافتكى، روابط بين فردى، و بازى و اوقات فراغت اسـت؛ و و حيطه مهارتهاى حر كتى شـامل زيربخشهاى مهارتهاى حر كتى درشـت و

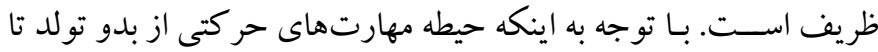

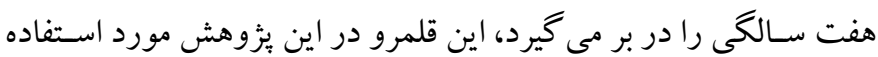

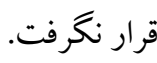

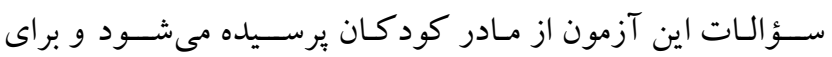

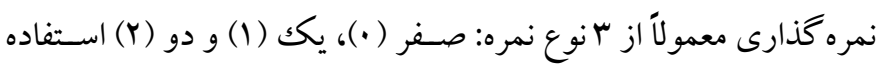

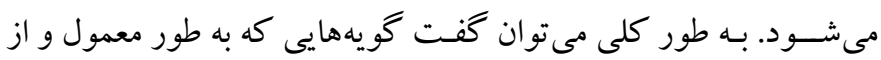

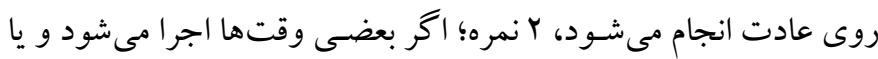

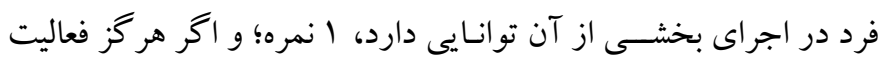

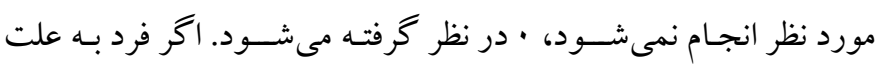
محسدوديـت مربوط بـه موقعيـتهـاى محيطى، فعاليت مورد نظر را انجام

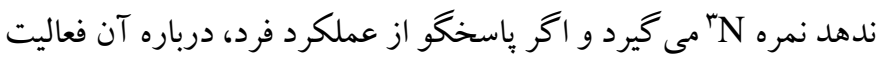

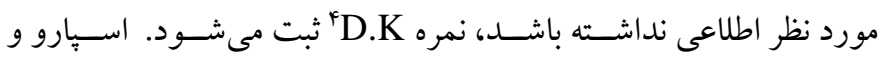
همكاران از ب روش براى محاسبه اعتبار استفاده كردند:

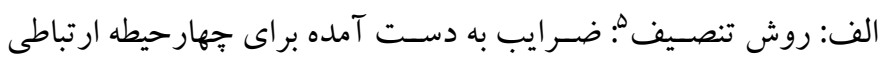

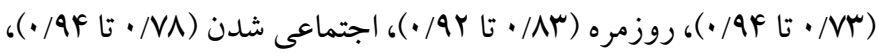

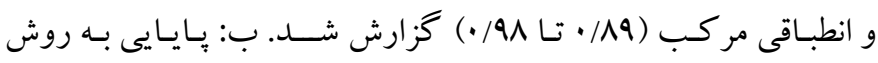

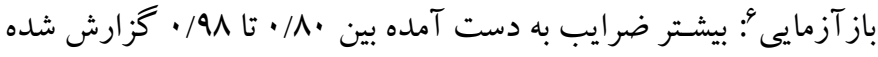

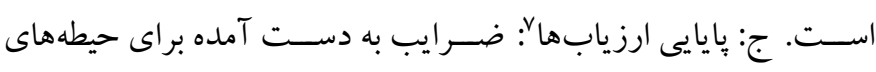

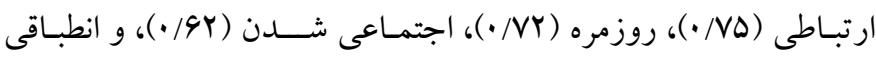
بر آورد شد. (•VF) روايى مقياس توسـط اسـهارو و همكاران با روشهاى روايى سـازهـ،

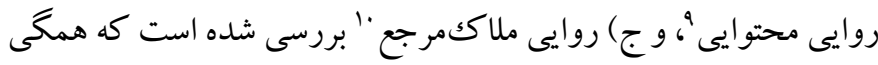

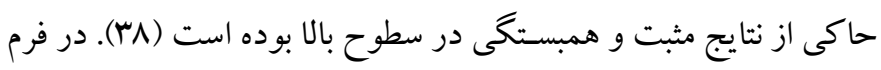

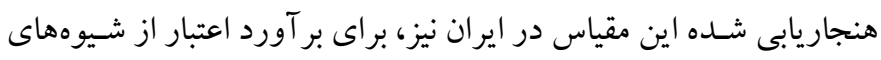

6. Test-retest

7. Interrater-reliability

8 . Construct- validity

9. Content validity

10. Criterion- related validity.
كو دكsرو در مناطق محروم شهر قم در سال آموزشى سو _ rar ا انجام شد.

\section{روش}

الف) طرح ئوهش و شر كت كنند

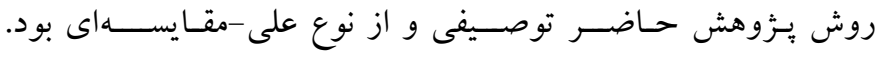

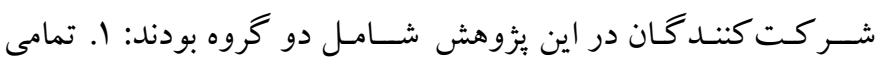

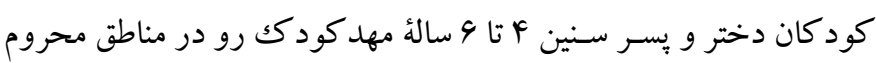

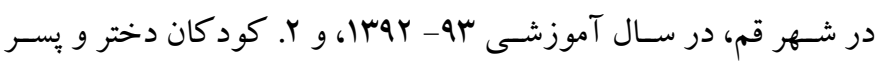
غير مهد كود ككرو همسـن و همجنس با خروه ال از همان مناطق و ســال

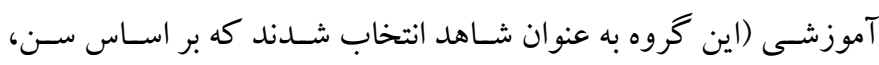

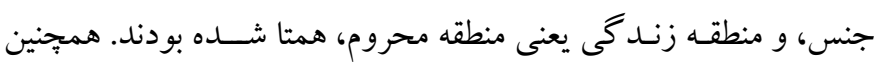

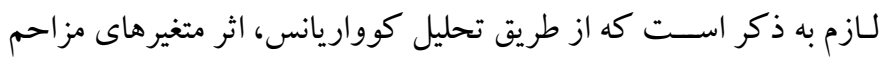

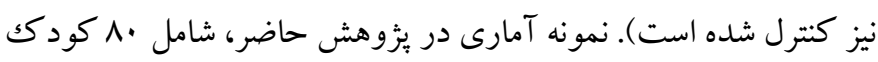

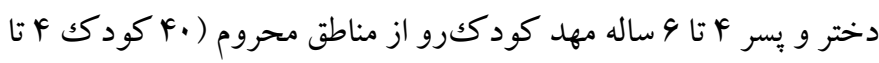

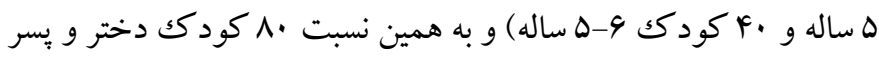

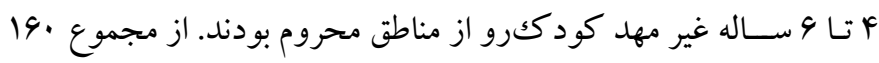

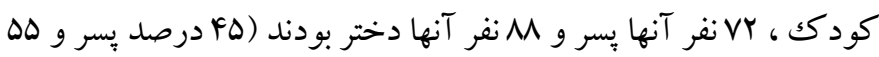

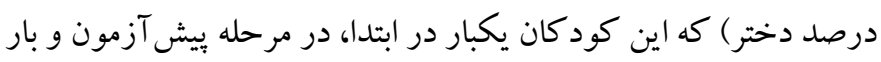

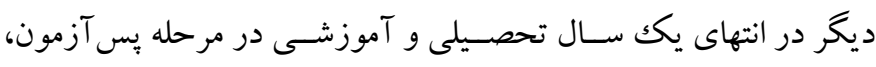

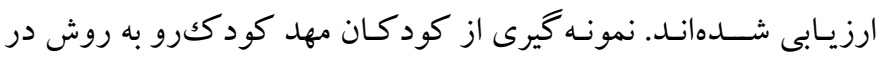

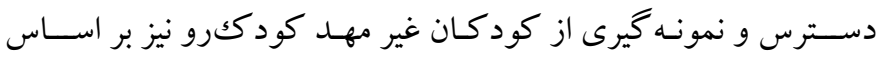

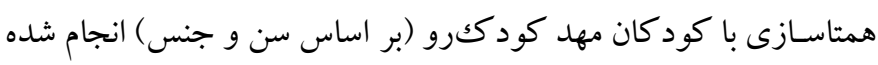

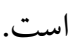

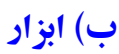

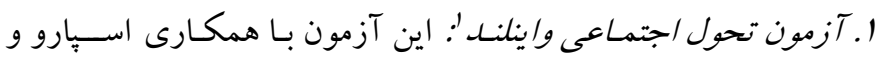

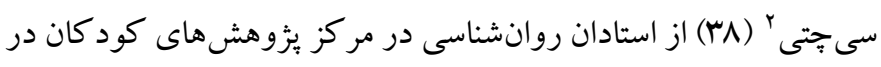

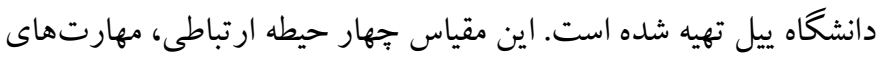

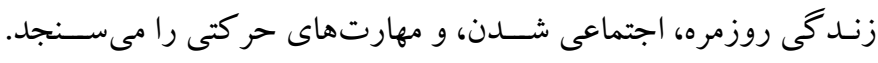

1. Vineland Adaptive Behavior Scales (VABS)

2. Sparrow \& Cicchetti

3. No-opportunity

4. Don't Know

5. Split-half 
مشكلات و نشانهها هستند كه تمايل به وقوع همزمان دارند. براى تشخيص نشـانگان در فهرسـت رفتارى كودك از روشهاى تحليل عوامل استفاده

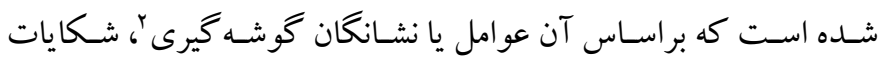

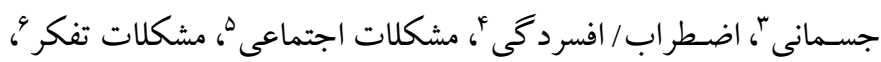

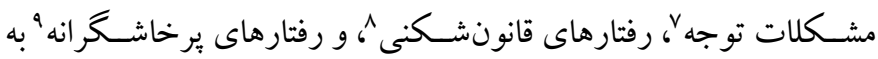
و جود آمدهاند كه سـه مورد نخست، تشكيل دهنده مشكلات دروننمود و دو مورد انتهايى تشكيل دهنده مشكلات بروننمود هستند. مى توان نمرات مربوط بـه اين دو مقياس را از مجموع نشــانگكانى كه در اين مقياس قرار مى گيرند، به دست آورد. همجنين از مجموع نمرات همه مقياس ها، نمره مشـكلات كلى به دست مى آيد. زيرمقياس هاى فهرست رفتارى كودك

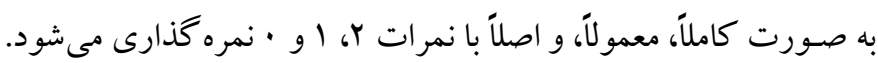
ضـريب باز آزمون بين مصساحبه گران نمرات فهرست رفتارى كود كك بين

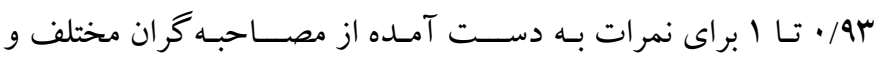
كزارشـات والدين با فاصله زمانى V روز به دست آمده است. اين ضريب اعتبـار براى مقياس هاى صــلاحيت، كنشورى ســازشــى، و نشــانكان هيجـانى - رفتـارى در فهرســت رفتارى كودك برابر 9/، بوده اسـت.

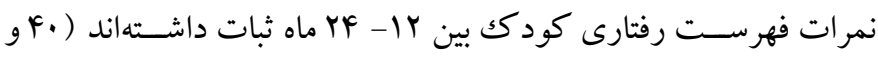
(F)). هنجـاريـابى اين نظام در شــهرســان تهران بر روى كود كان مقطع ابتدايى، راهنمايى و دبيرسـتان انجام شـده است. همسانى درونى اين نظام در مشكلات رفتارى - هيجانى كود كان رضايتبخش بوده است. همجنين در اعتبار آزمون-باز آزمون تمام همبســــى هاى كثــتاورى بيرســون معنادار بوده اسـت و تمام همبستخى هاى مربوط به توافق متقابل بين ياسخ دهند كان شـامل توافق بين والدين، معلمان، و كود كان معنادار بوده است (FY). در مطـالعـه مقـدماتى اين ئزوهش كه به منظور اعتباريابى ابزارهاى

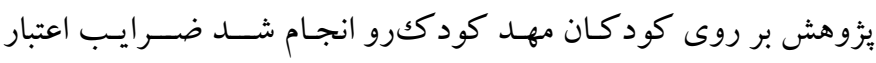
كرونباخ براى مشكلات بروننمود، دروننمود، و مشكلات كلى به ترتيب

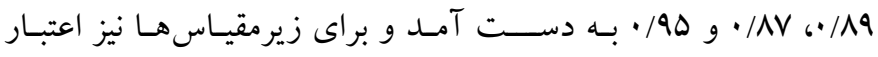
رضـايتبخشى به دست آمد. همبستكى فهرست رفتارى كود كك و همه

6. Thought problems

7. Attention problems

8. Delinquent behaviors

9. Aggressive behaviors
بازآزمايى و همبستِّى بين ارزيابـها استفاده شده است. در اين بررسى،

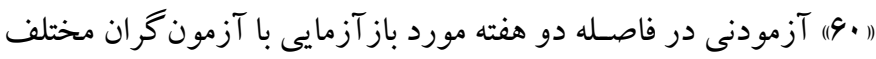

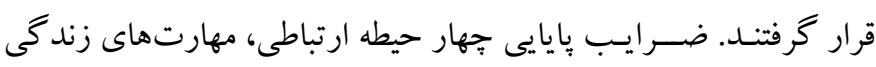
روزمره، اجتماعى شــدن، و مهارت هاى حر كتى و هميجنين حيطه كلى به

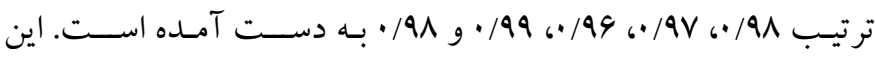
ضـرايب حاكى از يايايى بسـيار قابل ملاحظه مقياس مذكور اسـت. جهت بررسـى روايى ملاكى فرم هنجاريابى شــده واينلند در ايران، همبسـتحى نمرات مقياس رفتار انطباقى واينلند با نمرات برسـشــــامه هنجار شــده در ايران مورد بررسـى قرار گرفت كه VD/· به دسـت آمد و بيانكر روايى بالاى مقياس ياد شـده اسـت. جهت بررسى روايى افتراقى مقياس مذكور

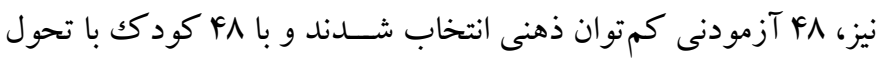
ذهنى بهنجار مقايسه شدند. نتايج نشان داد كه تفاوت بين ميانگين نمرات اين دو كروه با سطح اطمينان 99٪ در همه سنين معنى دار بوده است (وس). r. فهرسـت رفتارى كودكك ': اين فهرست كه در نظام سـنجش مبتنى بر تجربه آخنباخ ( • + براى ارزيابى سـنجش صلاحيت، كنشورى سازشى، و مشكلات هيجانى - رفتارى كود كان معرفى شده است توسط والدين يا فردى كه سـريرستى كودكى را بر عهده دارد و از او مراقبت مى كند و يا هر كسى كه با كودكك در محيطهاى شبهخانو اده زندكى مى كند و او را به طور كامل مى شــناسـد، بر اسـاس وضـعيت كودكك در 4 ماه كذشـته تكميل مى شـود. اين فهرست داراى دو بخش است: بخش نخست مربوط بـه صــلـاحيـت كودك در زمينـهــاى مختلف مـانـــ فعـاليتها، روابط اجتماعى، و مدرســهـ اســـ؛ و بخش دوم مربوط به مشـكلات هيجانى رفتارى اسـت كه مىتوان آن را به دو صورت مورد بررسى قرار داد. ابتدا مى توان از نيمرخهايى كه بر اســاس اختلال هاى راهنماى تشــخصـى و آمارى اختلالات روانى نســه جهارم تنظيم شــده اسـتفاده كرد كه اين جهـت گيرى مشــكلـات هيجـانى، اضـــر ابى، بـدنى، نـارســايى توجه / فزون كنشـى، تضــادورزى جسـور انه، و مشـكلات رفتار هنجارى را در برمى كيرد. همجينين مىتوان آن را بر اســاس مقياسهاى نشــانگًانى كه مبتنى بر تجربه هسـتند، مورد بررسـى قرار داد. نشــانگان، مجموعهاى از

1. Child Behavior Checklist (CBCL)

2. Withdrawn

3. Somatic complaints

4. Anxious/ depressed

5. Social problems 
رعايت شد. در پايان دادههاى حاصل از تكميل برسشنامهها پِ از جمع -

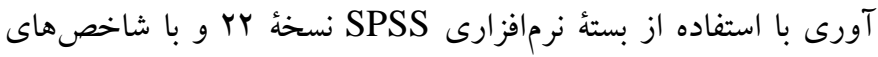

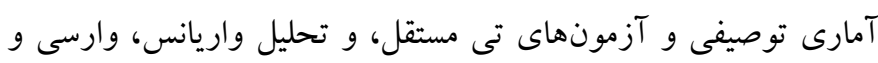
تحليل شدند.

\section{يافته ها}

در جدول ا شـاخص هاى توصسيفى شامل ميانخين و انحر اف استاندارد و

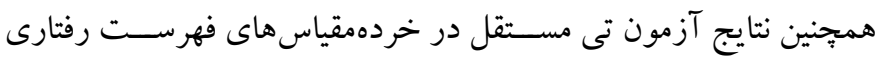

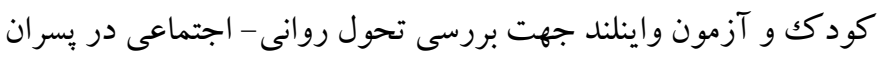
كز ارش شده است.
زيرمقياسهاى آن با شـاخص تنيدگى والدين ' در ســح 1 • • معنىدار

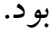

ج) روش اجرا :بر ایى جمع آورى دادهها، ابتدا به سازمان بهزيستى شهر قم احم

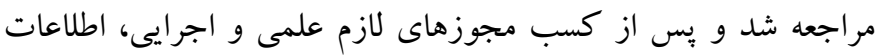

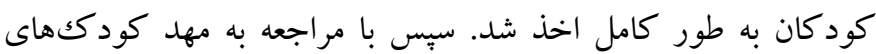
مختلف بر اساس شرايط ورود و خروج به مطالعه مانند رضايت كتبى

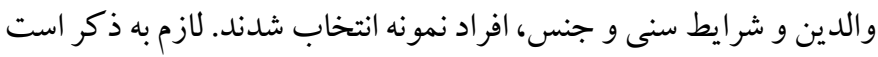
كه اطلاعات در دو مرحله ييش آزمون و يس آزمون (ابتدا و انتهاى سال

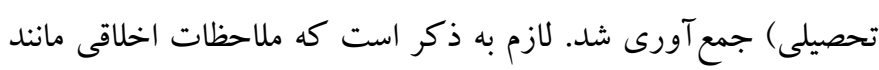

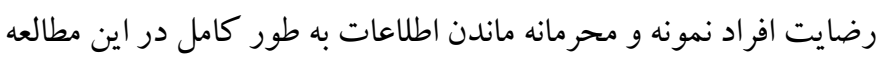

جدول ا: شاخصهاى توصيفى و نتايج آزمون تى مستقل جهت بررسى تحول روانى - اجتماعى در يسران

\begin{tabular}{|c|c|c|c|c|c|c|c|}
\hline سطح معنادارى & درجه آزادى & Tاره & تفاوت ميانكين & انحراف استاندارد & ميانكين & كروه & متغير \\
\hline \multirow[t]{2}{*}{.$/ \mathrm{IV}$} & $119 / 11$ & $r / r \mu$ & $\cdot / \Delta \Delta$ & D/AT & $19 / 11$ & مهد كودككرو & شكايت جسمانى \\
\hline & & & & - /Ar & $10 / 09$ & غيرمهد كودككرو & \\
\hline \multirow[t]{2}{*}{ 䄅䉼 $/ \cdot 1$} & $|r m / 1|$ & $r / \cdot 1$ & $r / 11$ & $\cdot / 49$ & $|f / \cdot|$ & مهد كودككرو & گُشه گيرى \\
\hline & & & & $\cdot / \mu F$ & $1 / / 9$ & غيرمهد كودككرو & \\
\hline \multirow[t]{2}{*}{ r } & $11 r / \cdot 1 r$ & $r / 11$ & $\cdot / \Lambda$ & $\cdot 109$ & $Y Y / \cdot \Lambda$ & مهد كودككرو & اضطراب/افسردگى \\
\hline & & & & . & $r / 9$ & غيرمهد كودكىرو & \\
\hline \multirow[t]{2}{*}{$* \cdot / F$} & $119 / 11$ & $r / \Delta \Delta$ & $1 / 9 V$ & .194 & $11 / \cdot v$ & مهدكودككرو & مشكلات ا. \\
\hline & & & & $\cdot / \Delta \Delta$ & $1 \pi / 1$ & غير مهد كود ككرو & \\
\hline \multirow[t]{2}{*}{ r } & $11 \cdot / r 1$ & $1 / \mathrm{VV}$ & $\cdot / \Delta$ & $\cdot / 4 q$ & $\mid V / I$ & مهدكودككرو & مشكلات تفكر \\
\hline & & & & $\cdot / F V$ & $1 V / 9$ & غيرمهد كودكىرو & \\
\hline \multirow[t]{2}{*}{.119} & $1 \cdot 1 / 14$ & $r / .9$ & $\cdot / f$ & $\cdot / \Delta \Lambda$ & $1 / / r$ & مهد كودككرو & مشكلات توجه \\
\hline & & & & $\cdot 191$ & $1 V / 9$ & غيرمهد كودككرو & \\
\hline \multirow[t]{2}{*}{$\cdot / 19$} & $11 \% / 19$ & $r / 19$ & $\cdot / 01$ & $\cdot / \mu$ & $1 Y / 9$ & مهد كودككرو & رفتارهاى قانونشكنى \\
\hline & & & & $\cdot|A|$ & $1 Y / \cdot 9$ & غيرمهد كودككرو & \\
\hline \multirow[t]{2}{*}{$* \cdot / \cdot F$} & $|r| / Y$ & $r / 4 Q$ & $1 / \Delta r$ & $\cdot / \Delta V$ & 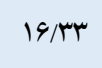 & مهدكود ككرو & رفتارهاى برخاشگر انه \\
\hline & & & & $\cdot / 4 q$ & $\mid F / \Lambda$ & غيرمهد كودككرو & \\
\hline \multirow[t]{2}{*}{ 米䉼 $/ \cdot 1$} & $|r \Delta / \cdot 1|$ & $r / Y$ & $F / 9 V$ & $\cdot / \mathrm{W}$ & $r F / \cdot V$ & مهد كودككرو & قلمرو ارتباطى \\
\hline & & & & $\cdot 199$ & $19 / 4$ & غيرمهد كودككرو & \\
\hline \multirow[t]{2}{*}{ 米西・ $/ \cdot 1$} & $|r V /| r \mid$ & $r / f r$ & $\Delta / r$ & $\cdot|\wedge|$ & L & مهد كودكرو & مهارتهاى زندگى روزمره \\
\hline & & & & $\cdot / r^{2}$ & $1 \wedge / \cdot 1$ & غيرمهد كودكروو & \\
\hline \multirow[t]{2}{*}{$* \cdot / \cdot r$} & سMF/IT & $\mathrm{r} / \wedge \mathrm{V}$ & $r / F I$ & $\cdot 199$ & $19 / \cdot 11$ & مهد كودككرو & اجتماعى شدن \\
\hline & & & & $\cdot / \Delta r$ & $19 / 9$ & غيرمهد كودكىرو & \\
\hline
\end{tabular}




\begin{tabular}{|c|c|c|c|c|c|c|c|}
\hline \multirow[t]{2}{*}{.$/ f F$} & $11 Y / 1 \cdot 1$ & $1 / 1 r$ & $\cdot / Y F$ & $\cdot / V \Delta$ & $10 / \cdot f$ & مهد كودككرو & مهارت هاى حر كتى \\
\hline & & & & $\cdot / 94$ & $\mid f / \Lambda$ & غير مهد كودككرو & \\
\hline \multirow[t]{2}{*}{$\cdot 111$} & $110 / 11 F$ & $1 / N r$ & $\cdot / \Delta r$ & .199 & $10 / 90$ & مهد كودكرو & نمره كلى مشكلات رفتارى \\
\hline & & & & $\cdot / v 1$ & $19 / 4 \Lambda$ & غيرمهد كودككرو & \\
\hline \multirow[t]{2}{*}{ 米西 $\cdot / \cdot 1$} & IrG/T & Y/৭४ & $r / l$ & $\cdot / A r$ & $r \cdot / r$ & مهد كودككرو & نمره كلى تحول اجتماعى \\
\hline & & & & $\cdot / V^{F}$ & $\mathrm{IV} / \mathrm{r}$ & غير مهد كودككرو & \\
\hline
\end{tabular}

ميانگين قلمرو ارتباطى، مهارتهاى زندگى روزمره، و اجتماعى شدن در

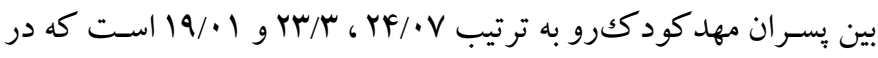

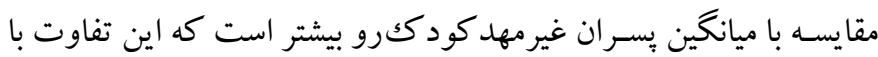

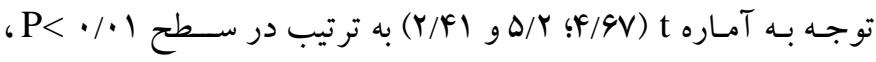

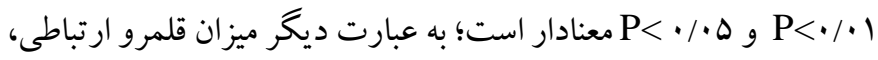

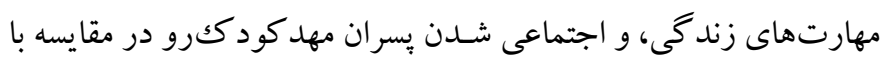

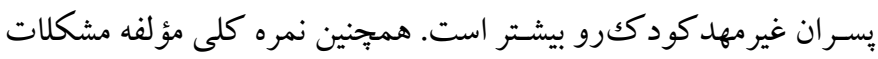

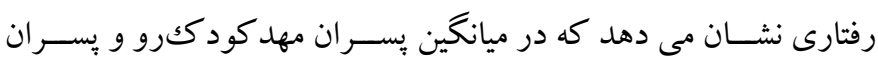

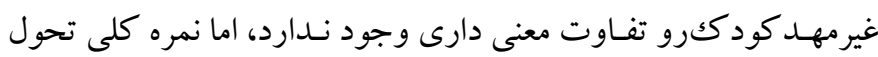

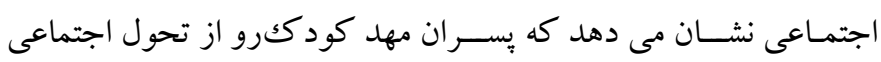

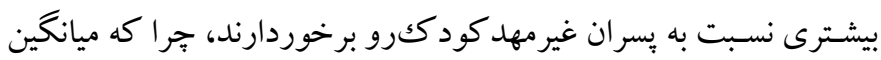

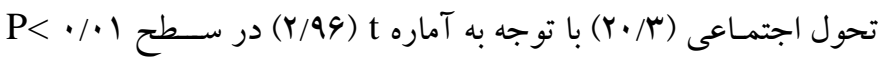

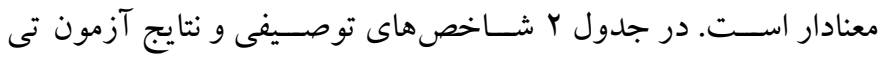
مسـتقل در خردممقياسهاى فهرسـت رفتارى كودكك و آزمون واينلند

جهت بررسى تحول روانى - اجتماعى در دختران گزارش شده است.
مندرجات جدول انشـان مى دهد كه ميانگين زيرمؤلفه هاى گوشـه

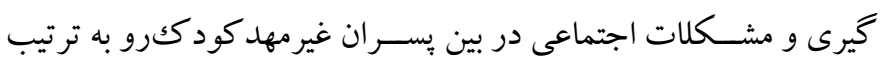

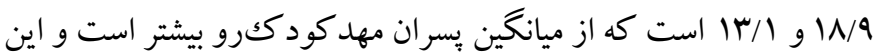

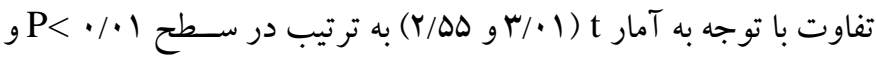

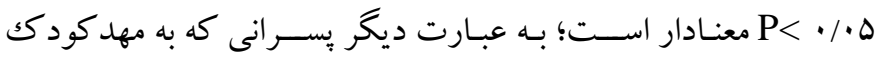

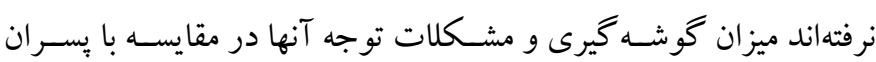

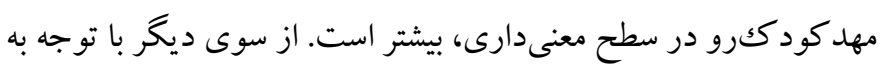

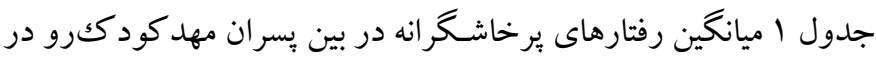

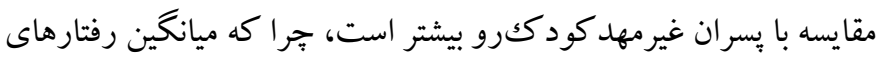

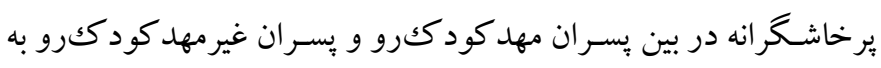

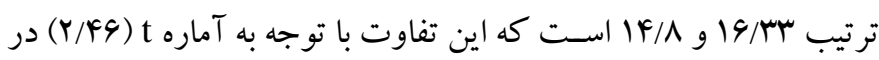

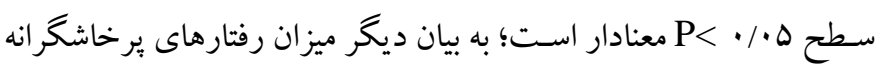

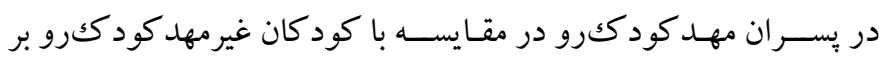
اســاس يـافتهـهـاى بزوهش حاضـــر در مناطق محروم شـهـر قم به طور

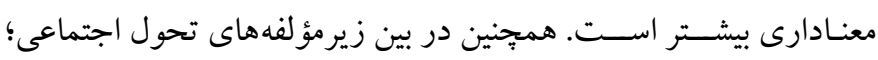

جدول r: شاخصهاى توصيفى و نتايج آزمون تى مستقل جهت بررسى تحول روانى - اجتماعى در دختران

\begin{tabular}{|c|c|c|c|c|c|c|c|}
\hline سطح معنادارى & درجه آزادى & t toر & تفاوت ميانغين & انحراف استاندارد & ميانكين & كروه & متغير \\
\hline \multirow[t]{2}{*}{ r } & $\|k /\|$ & $r / \pi r$ & $\cdot / 4 \Delta$ &.$/ 94$ & $\mid N / \cdot 1$ & مهد كودككرو & شكايت جسمانى \\
\hline & & & & $\cdot / V r$ & IV/DS & غير مهد كود ككرو & \\
\hline \multirow[t]{2}{*}{$* \cdot / r$} & $11 \cdot / 11$ & $r / \Delta 1$ & r/Aq & $\cdot / 4 \wedge$ & $11 / \cdot 1$ & مهد كودككرو & گُشه گيرى \\
\hline & & & & $\cdot / 4 F$ & $15 / 9$ & غيرمهد كود ككرو & \\
\hline \multirow[t]{2}{*}{.$/ 1 r$} & $I I V / \cdot r r$ & $r / r I$ & $\cdot / 1 \Lambda$ & $\cdot / v^{\prime}$ & $r \Delta / \cdot \wedge$ & مهد كودككرو & اضطراب/افسردگى \\
\hline & & & & •/Ar & $r F / 9$ & غير مهدكودككرو & \\
\hline \multirow[t]{2}{*}{$\% \cdot / \cdot 4$} & $11 N 11$ & $r / F \Delta$ & $1 / 4$ & . $/ \Delta r$ & $I T / V$ & مهد كودككرو & مشكلات اجتماعى \\
\hline & & & & . & $\mid f / 1$ & غير مهدكودككرو & \\
\hline \multirow[t]{2}{*}{ 每/ } & $|1 \cdot / r|$ & $1 / \mathrm{WV}$ & $\cdot / r$ & $\cdot / 49$ & $\mid r / 1$ & مهد كودككرو & مشكلات تفكر \\
\hline & & & & $\cdot / A V$ & $\mid r / A$ & غيرمهد كود ككرو & \\
\hline \multirow[t]{2}{*}{.$/ 11$} & $1.9 / \cdot r$ & $r / 19$ & $\cdot / \wedge$ & $\cdot / 91$ & $11 / r$ & مهد كودكرو & مشكلات توجه \\
\hline & & & & $\cdot / \mathrm{NI}$ & $\mid r / 1$ & غير مهد كودككرو & \\
\hline
\end{tabular}




\begin{tabular}{|c|c|c|c|c|c|c|c|}
\hline \multirow[t]{2}{*}{.$/ 19$} & $11 f / 19$ & $r / 19$ & $\cdot / 01$ & $\cdot /$ / & $1 Y / 9$ & مهد كودككرو & رفتار هاى قانو نشكنى \\
\hline & & & & $\cdot|4|$ & $1 Y / \cdot 9$ & غيرمهد كود ككرو & \\
\hline \multirow[t]{2}{*}{.$/ .9$} & IrI/Ir & $r / Y q$ & •/Ar & $\cdot / \Delta V$ & $10 / \cdot 1$ & مهد كودككرو & رفتارهاى يرخاشخرانه \\
\hline & & & & $\cdot / 4 q$ & $|F /| \Lambda$ & غيرمهد كودككرو & \\
\hline \multirow[t]{2}{*}{ **** $\cdot / \cdot 1$} & $1 r \Delta / \cdot 11$ & $r / 91$ & $9 / 1 \pi$ & $\cdot / \wedge \mathrm{V}$ & rq/IV & مهدكودككرو & قلمرو ارتباطى \\
\hline & & & & .199 & $r \cdot / . r$ & غير مهد كود ككرو & \\
\hline \multirow[t]{2}{*}{ 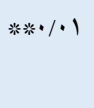 } & $|r V / I r|$ & $r / 4 r$ & $\Delta / r$ & • & $r F / \cdot \Lambda$ & مهد كودككرو & مهارتهاى زندگى روزمره \\
\hline & & & & $\cdot / \wedge 1$ & $r Y / \cdot 1$ & غيرمهدكود ككرو & \\
\hline \multirow[t]{2}{*}{ 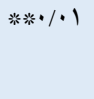 } & $1 \times q / 1 \cdot r$ & r/AV & $r / \cdot v$ & $\cdot 199$ & $19 / \cdot 11$ & مهل كودككرو & اجتماعى شدن \\
\hline & & & & $\cdot / \Delta r$ & $19 / 9$ & غير مهد كود ككرو & \\
\hline \multirow[t]{2}{*}{$\cdot /$} & $\| r / 1 \cdot 1$ & 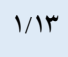 & $\cdot 19 \mathrm{~V}$ & $\cdot / \mathrm{NI}$ & $\mid F / \cdot r$ & مهد كودككرو & مهارتهاى حر كتى \\
\hline & & & & $\cdot 194$ & $\mid F / V$ & غيرمهدكود ككرو & \\
\hline \multirow[t]{2}{*}{ r } & $1 \cdot Y / 1$ & $\cdot / 91$ & $\cdot / \Delta$ & $\cdot / \Delta 9$ & $\mid F / \Lambda$ & مهد كودككرو & نمره كلى مشكلات رفتارى \\
\hline & & & & $\cdot / \Delta \Lambda$ & $\mid F / r$ & غيرمهد كود ككرو & \\
\hline \multirow[t]{2}{*}{$* \cdot / \cdot 1$} & $119 / .94$ & $r / 91$ & $r / V$ & $\cdot / \mathrm{VV}$ & $r \cdot / \wedge$ & مهد كو دكترو & نمره كلى تحول اجتماعى \\
\hline & & & & .190 & $1 N / 1$ & غيرمهد كودككرو & \\
\hline
\end{tabular}

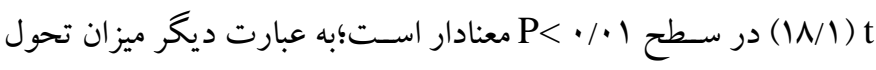

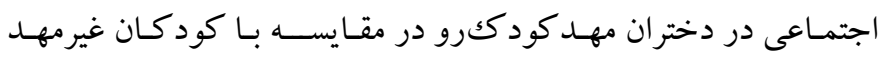

$$
\text { كودكرو بيشتر است. }
$$

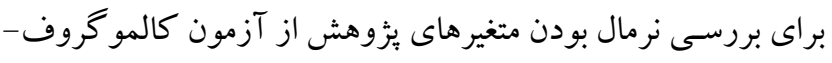

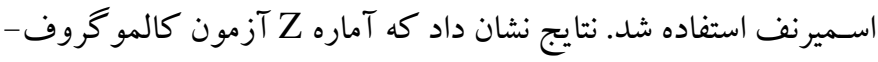
اسـميرنف براى تمامى متغيرهاى يزووهش در گروه هاى مورد مطالعه در

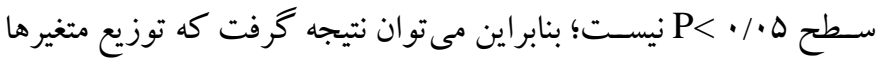

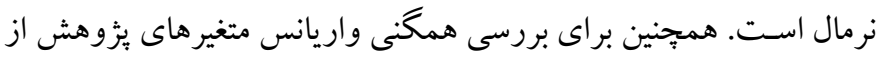

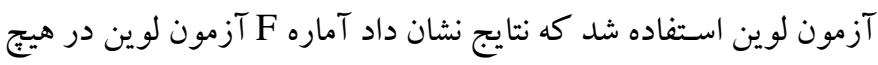

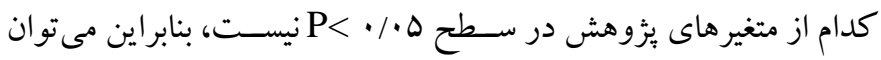

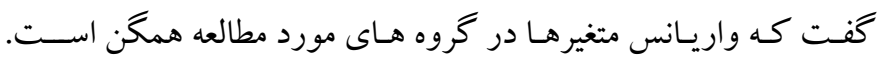
همجِنين براى بررسـى همخنى ماتريس كوواريانس در متغيرهاى وابسـته

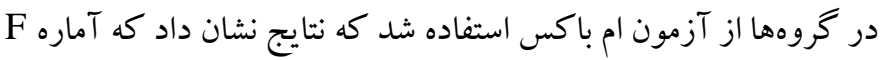

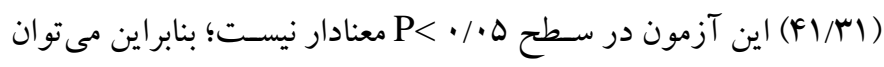

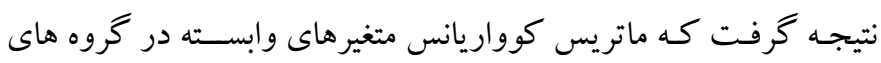

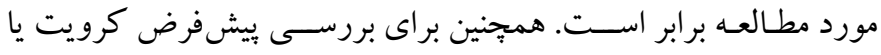

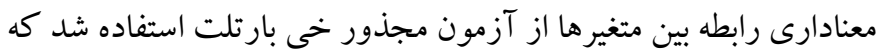

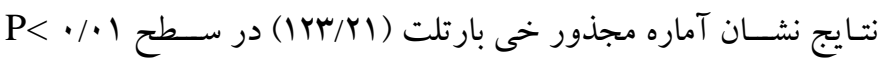

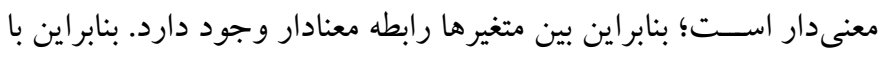

منـدرجـات جـدول r نشـــان مى دهــ كـه ميـانگين زيرمؤلفـه هـاى

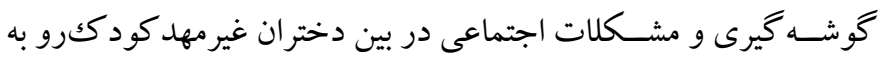

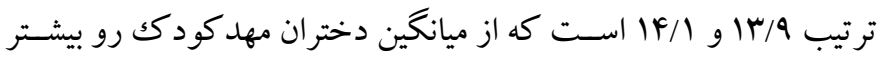

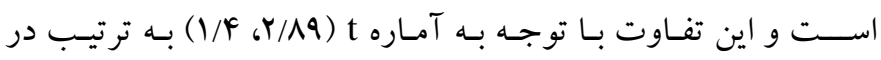

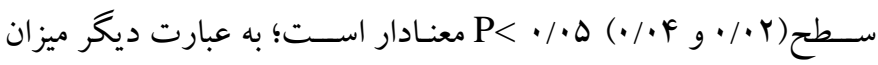

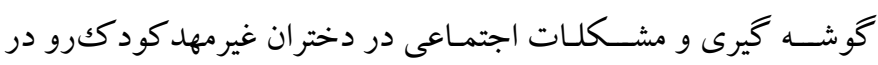

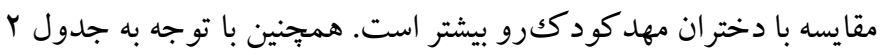

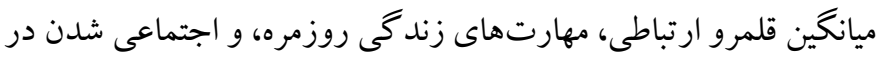

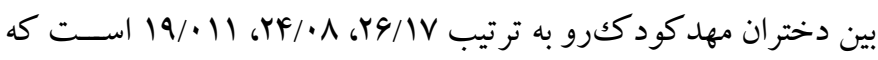
در مقايسه با ميانخين دختران غيرمهدكود دكرو بيشتر است و اين تفاوت

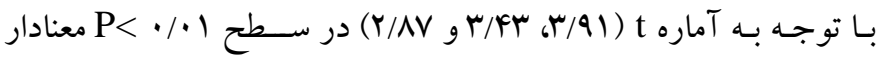
اســت؛ بـه عبـارت ديخر دختران مهـد كودككرو در مقايســه با دختران

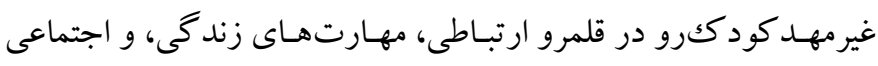
شدن در وضعيت بهترى هستند.

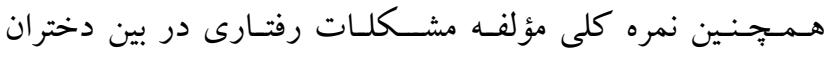
مهـدكودككرو و دختران غيرمهـد كودككرو تفاوت معنى دارى ندارد. از سـوى ديخردر نمره كلى تحول اجتماعى بين دختران مهدكود ككرو در درد

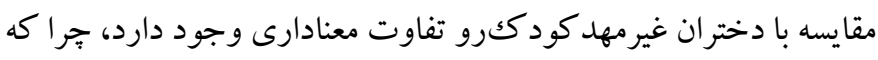

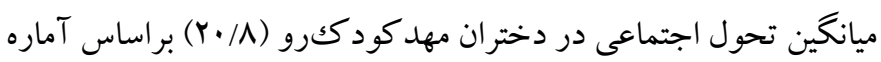


توجـهـ بـه محقق شـــدن تمـامى ييشفرض هاى تحليل واريانس از آزمون

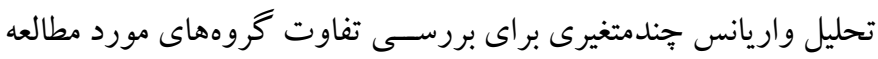

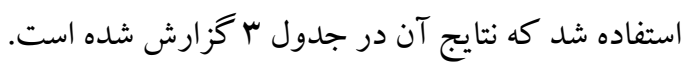

جدول "ن نتايج آزمون تحليل واريانس جندمتغيرى در كروههاى مورد مطالعه

\begin{tabular}{|c|c|c|c|c|c|c|}
\hline اندازه اثر & سطح معنا دارى & df 2 & df 1 & $\mathbf{F}$ & Tاره & آزمون \\
\hline$\cdot / \cdot v$ &.$/ \cdot 1$ & roq & 11 & r/AG & $\cdot / 49$ & اثر ييلايى \\
\hline$\cdot / \cdot \wedge$ &.$/ .1$ & ros & 11 & $F / 1$ & $\cdot / \mathrm{VA}$ & لامبداى ويلكز \\
\hline
\end{tabular}

اينكـهـ گروههـا در كدام يكك از متغيرهاى مورد مطالعه با يكديخر تفاوت

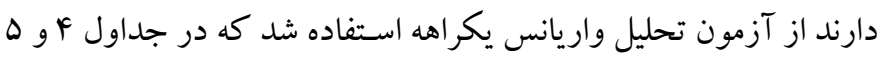
كزارش شدهاند.
منـدرجـات جـدول ب نشـــان مىدهد كه آزمون اثر بيلايى و لامبداى

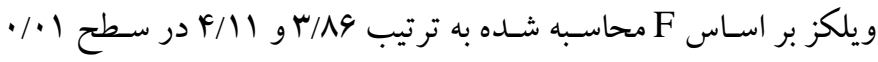

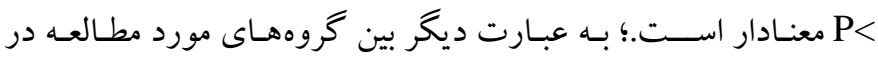

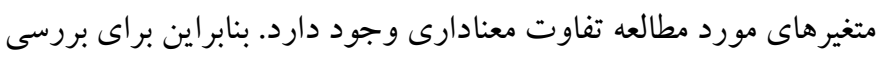

جدول ع: نتايج تحليل واريانس يكراهه جهت بررسى تفاوت يسران شر كت كننده در يزوهش در ميزان متغير هاى مشكلات رفتارى و تحول اجتماعى

\begin{tabular}{|c|c|c|c|c|c|c|c|}
\hline اندازه اثر & $\mathbf{P}$ & $\mathbf{F}$ & خطا MS & كروه MS & خطا SS & كروه SS & متغير \\
\hline.$/ \cdot 1$ & $\cdot / 4 q$ & $\cdot / v$ & $I V / I Y$ & $1 r / Y q$ & FOAV & $F q / 1 r$ & مشكلات رفتارى \\
\hline $.1 \cdot 9$ &.$/ \cdot 1$ & N/r & $Y F / F G$ & IVA/VG & VYGD/IF & $r V \Delta / \Delta r$ & تحول اجتماعى \\
\hline
\end{tabular}

كود كsرو، تفـاوت معنـادارى دارد كـه اين تفاوت در ســطح 1. معنادار اســـ؛ به طورى كه اندازه اثر 9 •/ • حاكى از آن اسـت كه اين تفاوت سـطح متوسط است و همجنين ميزان تفاوت ميانخين ها در جدول ا قابل مشاهده است.
مندرجات جدول F نشــان مىدهد كه آماره F براى مؤلفه مشـكلات رفتـارى (•V/•) در بين دو كروه يســران مهـد كودككرو و غيرمهـد كودككرو تفـاوت معنـادارى ندارد. از ســوى ديخر آماره F براى مؤلفه

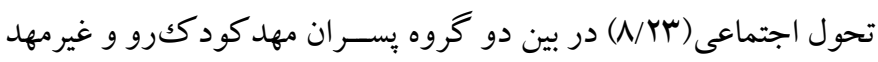

\begin{tabular}{|c|c|c|c|c|c|c|c|}
\hline اندازه اثر & $\mathbf{P}$ & $\mathbf{F}$ & خطا MS & تروه MS & خطا SS & SS كروه SS & متغير \\
\hline.$/ .1$ & .190 & $\cdot / \mu \Lambda$ & $r \cdot 109$ & $V / 91$ & $91 \cdot V / 99$ & $19 / Y Y$ & مشكلات رفتارى \\
\hline .1 .9 &.$/ \cdot 1$ & $19 / 14$ & I I & MFT/VI & GMTK/YK & $9 N V / F Y$ & تحول اجتماعى \\
\hline
\end{tabular}

\section{بحث و نتيجه كيرى}

يثزوهش حاضـر با هدف مقايسه تحول روانى - اجتماعى در كود كان بسر و دختر f تا 9 ساله مهد كودككرو و غيرمهد كودككرو در مناطق محروم شـهر قم انجام شـد. نتايج نشـان داد تحول اجتماعى (در حيطههاى قلمرو ارتبـاطى، مهارتهاى زندكى روزمره، اجتماعى شـــدن در بــــــان مهد كودككرو در مقايسه با بِران غيرمهد كودككرو، متفاوت و بيشتر است؛

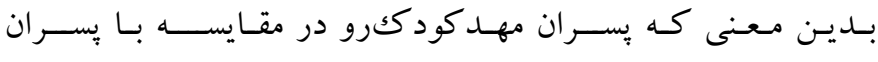
غيرمهـد كودككرو، تحول اجتمـاعى بيشــرى دارنسل. همجِنين در بين
مندرجات جدول ه نشـان مى دهد كه آماره F براى مؤلفه مشـكلات رفتـارى (Nא/•) در بـين دو كروه دختران مهـد كودككرو و غيرمهـد كودككرو تفـاوت معنـادارى ندارد. از ســوى ديكر آماره F براى مؤلفه تسحول اجتمـاعى(س/19/1) در بين دو كروه دختران مهـدكودككرو و غيرمهد كودككرو تفاوت معنادارى دارد كه اين تفاوت در ســطح 1 • • معنادار اسـت؛ به طورى كه اندازه اثر 9 • > • به دسـت آمد كه نشـان مى دهد تفاوت در سـطح متوسط است. هميجنين ميزان تفاوت ميانگينها در جدول r قابل مشاهده است. 
برقرارى ارتباط با ديخران و جامعه، اصـول اوليه زندگى و تحصـيلى را

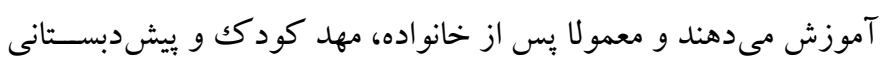

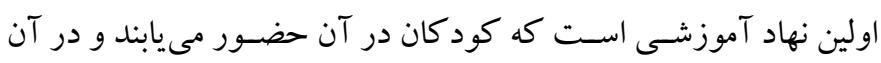

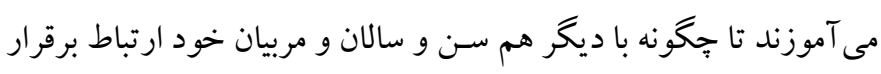

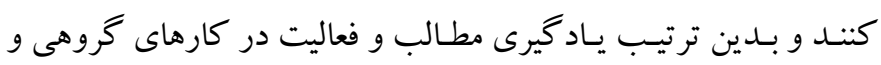
كلـاسـى بـاعـث مى شــود تا كود كان به خود باورى رســيده و اعتماد

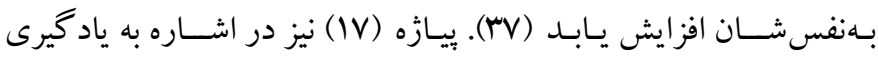

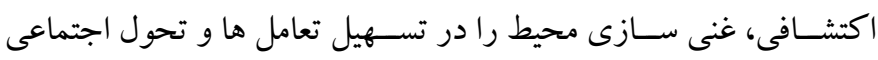
كودكى به طورى كه به كشـف مستقل از طرف كود كك منجر شود مهم

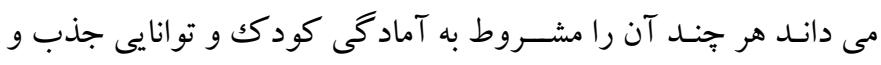

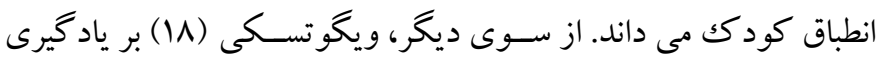
اكتشــــى هدايت شــده تاكيد مى كند، به طورى كه شــكل كيرى كليه

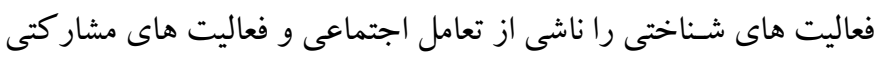

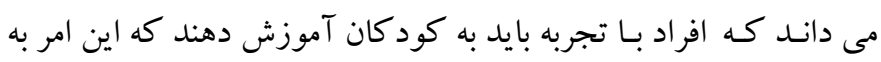
نقش مهم مربى به ويزه در ارتباط اشـاره مى كند. بنابر اين به نظر مى بـ درسد

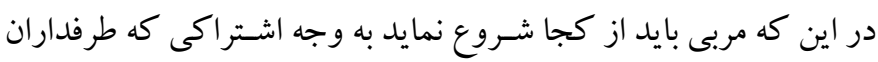

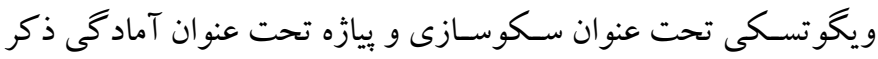
كرده اسـت مى رسيم. از سوى ديخر، نظريه شناختى - اجتماعى بندورا

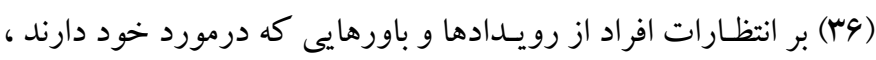

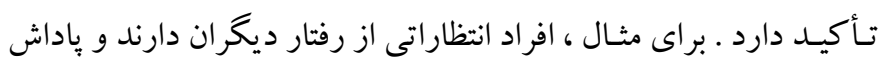
ها و تنبيه هايى را براى رفتار خود در موقعيتهاى مختلف توقع مى كنند.

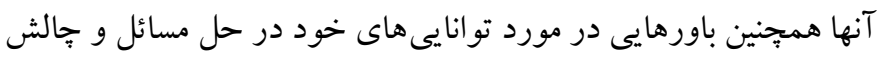

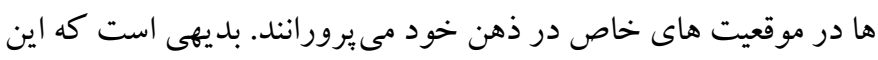

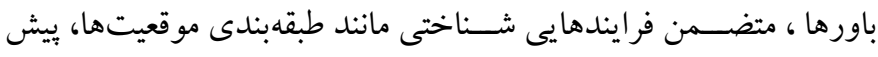

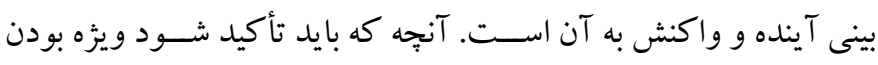

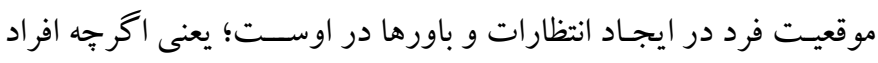

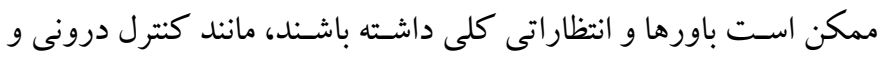
انتظارات تعميم يافته اى كه راتر مطرح مى كند، آن جهه كه مهم تر است،

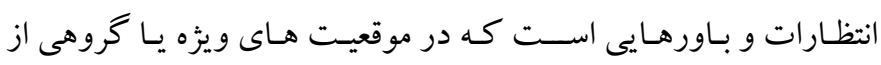
موقعيـت ها شــكل مى گيرد. وقتى نتوانيم موقعيت ها را از يكديخر تميز وهيز

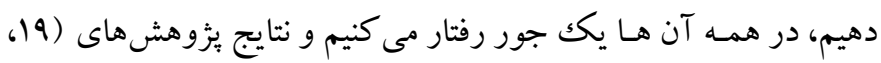

2. Self-directing
دختران مهد كود ككرو و دختران غيرمهد كودككرو نتيجه مشابه با بسران

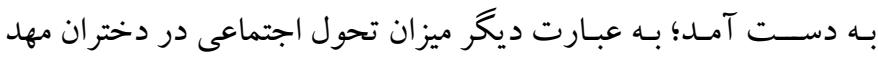

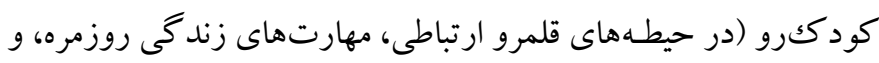

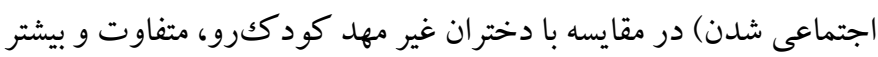

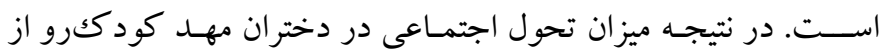

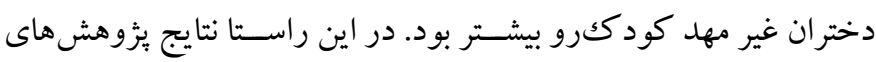

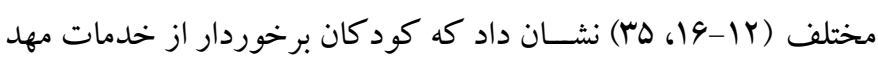

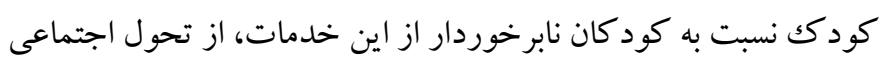
بالاترى برخوردارند، مشـكلات اجتماعى كمترى را تجربه مى كنند، و نيز

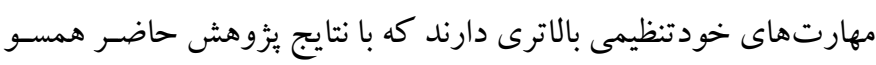

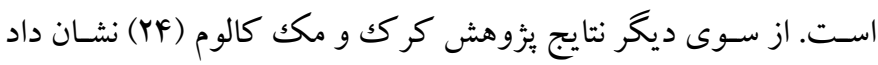

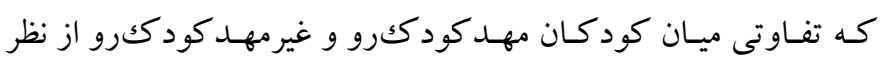
تحول اجتماعى وجود ندارد كه با نتايج يثزوهش حاضر، ناهمسو است.

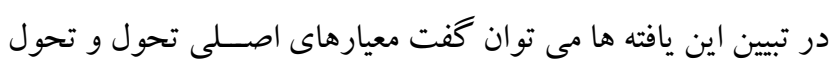

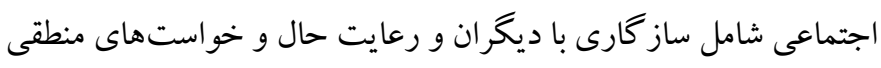

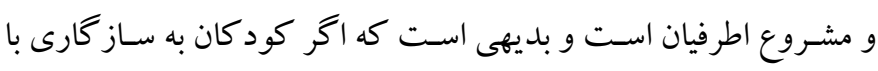

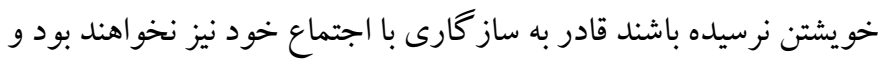

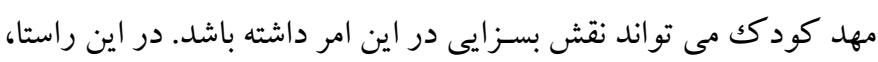

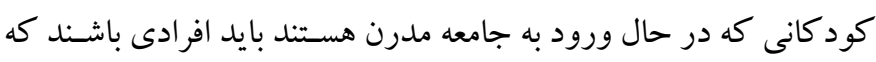

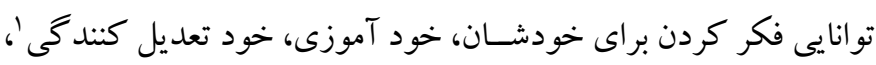

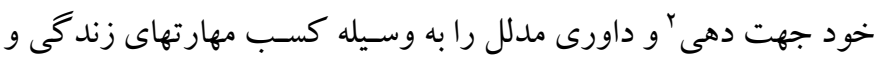

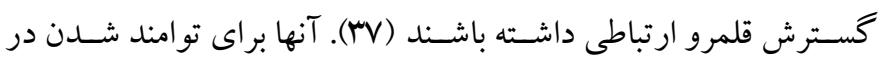

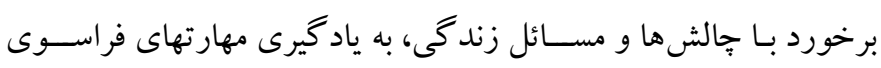

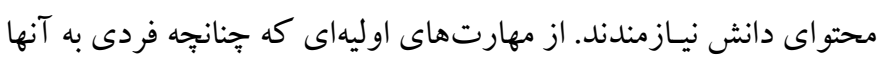

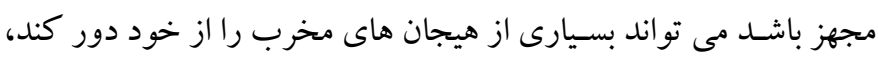

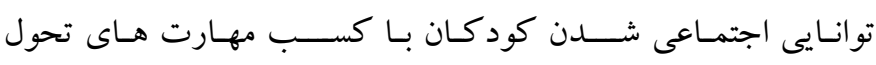

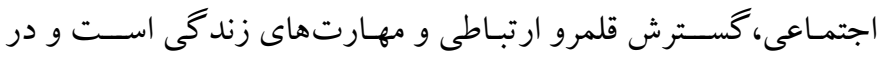

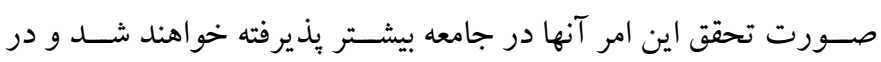

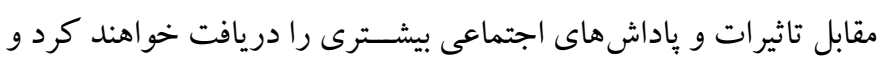

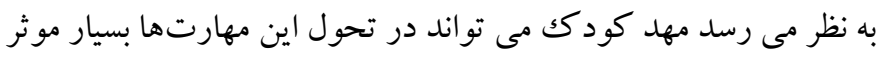

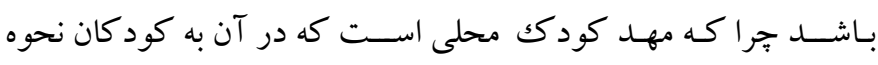

1. Self-modulation 
مراكز مر اقبـت روزانه از كود كان غيرمهد كودككرو ببشــتر اسـتـ كه با

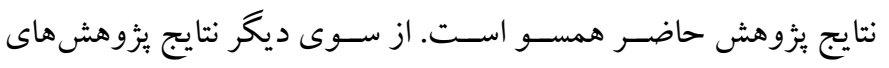

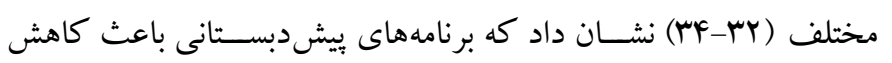

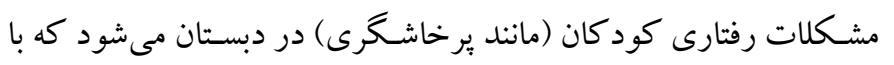

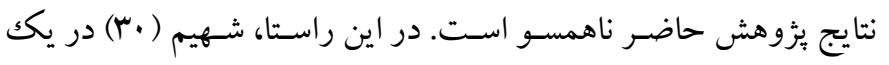

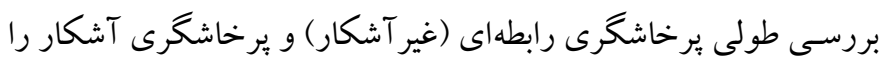

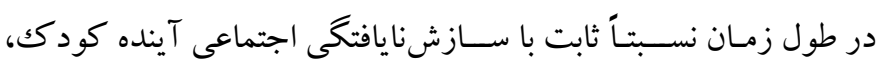

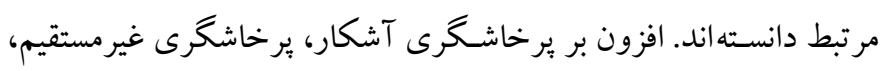

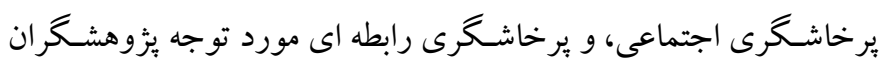

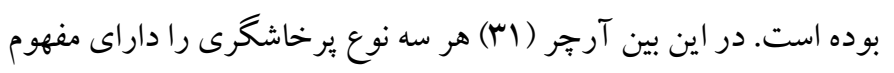

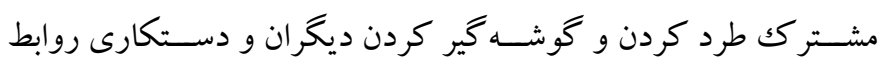

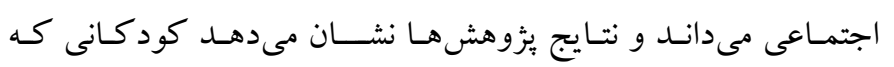

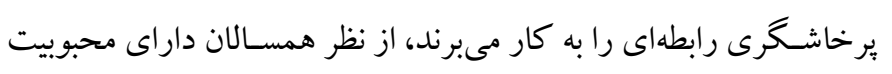

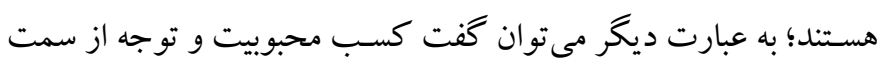

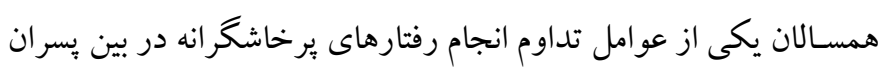

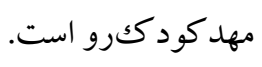

بثزوهش حاضــر همانند هر مطالعه ديخر محدوديت هايى را به همراه

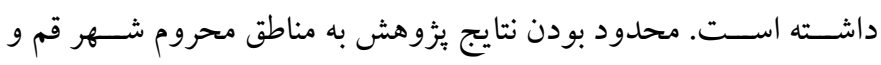

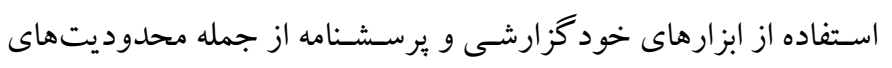

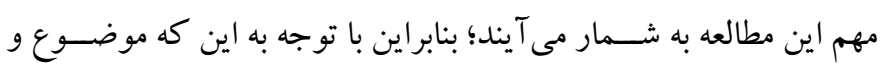

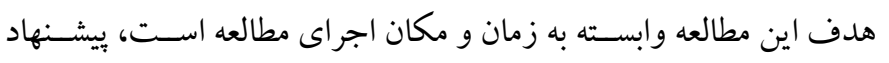

$$
\text { مىشود تعميمدهى نتايج با احتياط انجام شود. }
$$

تشـكر و قدردانى: اين بزوهش بر كرفته از طرح برزوهشى مصـوب سـازمان

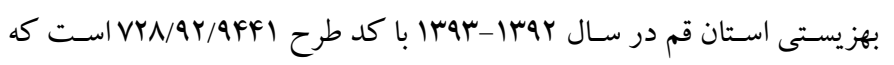

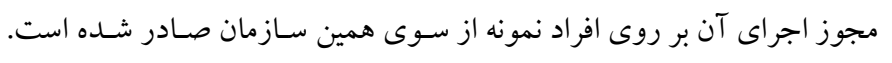

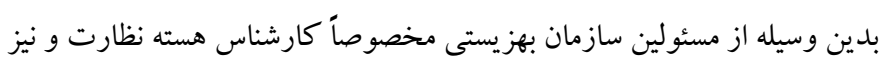

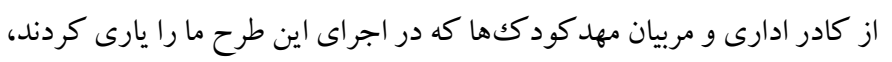

$$
\text { تشكر و قدردانى مىشود. }
$$

تضــاد منافع: هيج گونه تضــاد منافع در بين نويســدكان اين بثوهش وجود

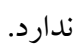

• نشــان مى دهـدكود كـانى كـه قبل از مدرســه دوره مهد كودكى را

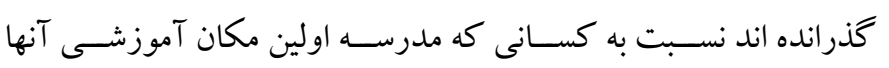

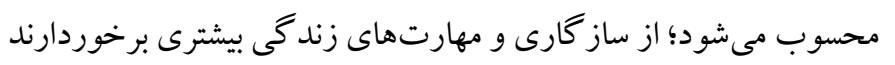

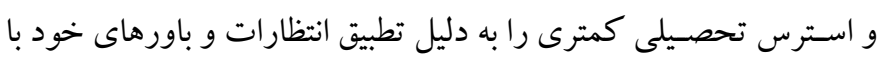
محيط تجربه مى كنند.

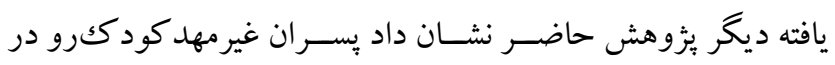

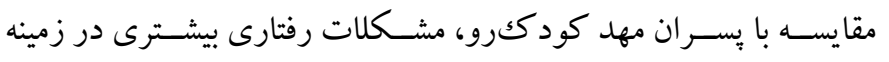

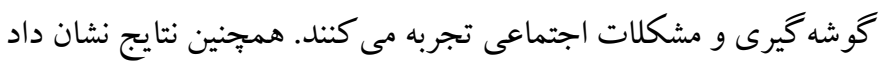

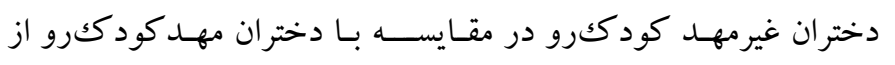

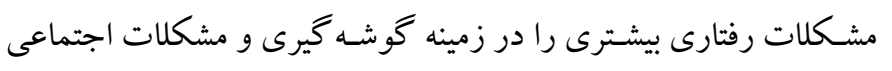

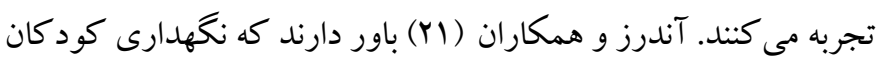
در كود كســـان بر تحول اجتمـاعى و هيجـانى آنـان تـأثير مثبتى دارد.

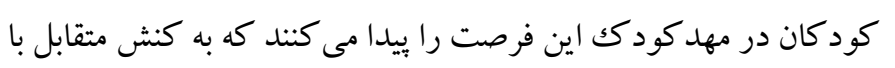

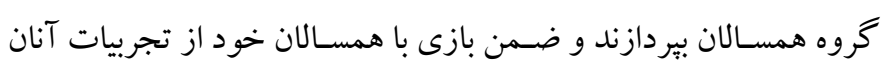

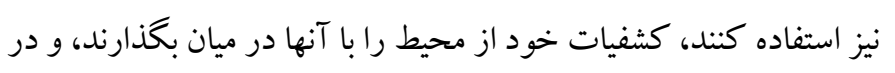

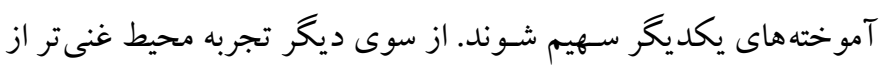

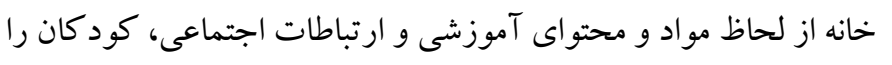

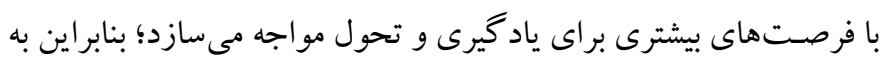

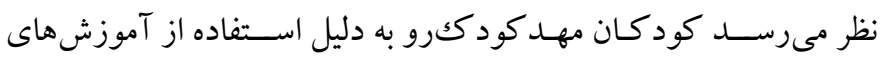

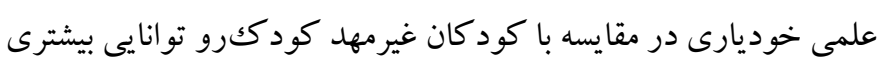
در سـازش با محيط دارند و مىتوانند در مهار كرى و مديريت صـيحيح

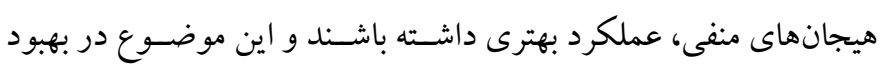

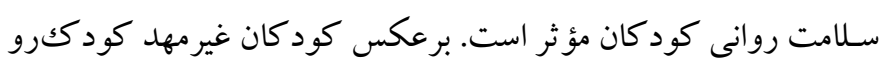

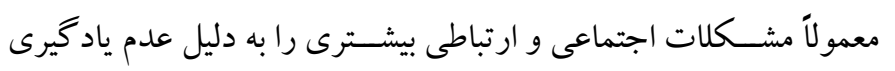
مهارت هاى ارتباطى و عدم گسترش قلمرو ارتباطى در مقايسه با كود كان

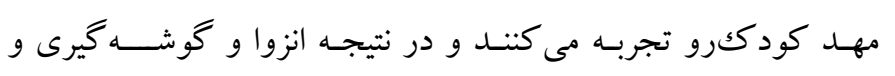
سازشنايافتكى بيشترى را تجربه مى كنند (YY).

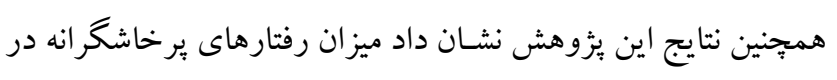

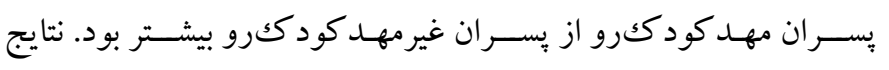

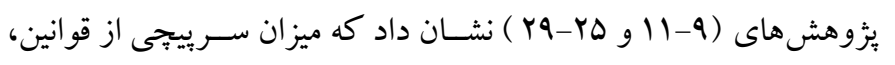

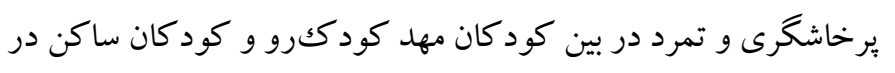




\section{References}

1. Yoon J, Martin LA. Infusing culturally responsive science curriculum into early childhood teacher preparation. Res Sci Educ. 2019; 49(3): 697-710. [Link]

2. Nekitsing C, Hetherington MM, Blundell-Birtill P. Developing healthy food preferences in preschool children through taste exposure, sensory learning, and nutrition education. Curr Obes Rep. 2018; 7(1): 60-67. [Link]

3. Rucinski CL, Brown JL, Downer JT. Teacher-child relationships, classroom climate, and children's social-emotional and academic development. J Educ Psychol. 2018; 110(7): 992-1004. [Link]

4. Blair C, McKinnon RD, Daneri MP. Effect of the tools of the mind kindergarten program on children's social and emotional development. Early Child Res Q. 2018; 43: 52-61. [Link]

5. Farid Marandi B, Kakabaraee K, Hosseini SS. The effect of training problem-solving on maladapted behavior of pre-school children. Iranian Journal of Educational Sociology. 2019; 2(4): 24-32. [Persian]. [Link]

6. Milne MK. Development and evaluation of an autonomous, virtual agent based social skills tutor for children with autism [Doctoral dissertation]. [Adelaide, South Australia]: College of Science and Engineering, Flinders University; 2018, pp: 1-188. [Link]

7. Gresham FM, Elliott SN, Metallo S, Byrd S, Wilson E, Cassidy K. Cross-informant agreement of children's social-emotional skills: An investigation of ratings by teachers, parents, and students from a nationally representative sample. Psychol Sch. 2018; 55(2): 208-223. [Link]

8. Carr RC, Mokrova IL, Vernon-Feagans L, Burchinal MR. Cumulative classroom quality during prekindergarten and kindergarten and children's language, literacy, and mathematics skills. Early Child Res Q. 2019; 47: 218-228. [Link]

9. Caemmerer JM, Keith TZ. Longitudinal, reciprocal effects of social skills and achievement from kindergarten to eighth grade. J Sch Psychol. 2015; 53(4): 265-281. [Link]

10. Mason AE. Longitudinal and reciprocal effects of primary school students' self-regulation and achievement [Doctoral dissertation]. [Pennsylvania, United States]: College of Education, the Pennsylvania State University; 2018, pp: 1-70. [Link]
11. Shehu BP. Peer acceptance in early childhood: Links to socio-economic status and social competences. J Soc Stud Educ Res. 2019; 10(4): 176-200. [Link]

12. Movahedzadeh B, Safaei-Ardakani R. Comparing social development, cognitive-motor development and behavioral problems of first grade female students in primary school with and without kindergarten service. Salamat ijtimai (Community Health). 2018; 5(1): 48-56. [Link]

13. Schoemaker K, Mulder H, Deković M, Matthys W. Executive functions in preschool children with externalizing behavior problems: A meta-analysis. J Abnorm Child Psychol. 2013; 41(3): 457-471. [Link]

14. Chen JJ-L. Gender differences in externalising problems among preschool children: Implications for early childhood educators. Early Child Dev Care. 2010; 180(4): 463-474. [Link]

15. Hall J, Sylva K, Sammons P, Melhuish E, SirajBlatchford I, Taggart B. Can preschool protect young children's cognitive and social development? Variation by center quality and duration of attendance. Sch Eff Sch Improv. 2013; 24(2): 155-176. [Link]

16. Loeb S, Bridges M, Bassok D, Fuller B, Rumberger RW. How much is too much? The influence of preschool centers on children's social and cognitive development. Econ Educ Rev. 2007; 26(1): 52-66. [Link]

17. Hanfstingl B, Benke G, Zhang Y. Comparing variation theory with Piaget's theory of cognitive development: More similarities than differences? Educ Action Res. 2019; 27(4): 511-526. [Link]

18. Quinn H. Jean Piaget and Lev Vygotsky. IU South Bend Undergraduate Research Journal. 2019; 19: 7191. [Link]

19.Loukatari P, Matsouka O, Papadimitriou K, Nani S, Grammatikopoulos V. The effect of a structured playfulness program on social skills in kindergarten children. International Journal of Instruction. 2019; 12(3): 237-252. [Link]

20.Rusmayadi R, Herman H. Effects of social skills on early childhood independence. Journal of Educational Science and Technology (EST). 2019; 5(2): 159-165. [Link]

21. Anders Y, Grosse C, Rossbach H-G, Ebert S, Weinert S. Preschool and primary school influences on the development of children's early numeracy skills between the ages of 3 and 7 years in Germany. Sch Eff Sch Improv. 2013; 24(2): 195-211. [Link]

22. Vasileva M, Petermann F. Attachment, development, and mental health in abused and neglected preschool 
children in foster care: A meta-analysis. Trauma Violence Abuse. 2018; 19(4): 443-458. [Link]

23.Đurić-Zdravković A, Japundža-Milisavljević $M$, Milanović-Dobrota B, Banković S. Play and social skills of kindergarten children with mixed specific developmental disorders. Specijalna edukacija i rehabilitacija. 2019; 18(4): 419-441. [Link]

24. Kirk G, MacCallum J. Strategies that support kindergarten children's social and emotional development: One teacher's approach. Australas J Early Child. 2017; 42(1): 85-93. [Link]

25. Daniels S. Can pre-school education affect children's achievement in primary school? Oxf Rev Educ. 1995; 21(2): 163-178. [Link]

26.Akcan A, Ergun A. The effect of an aggressive behavior prevention program on kindergarten students. Public Health Nurs. 2019; 36(3): 330-340. [Link]

27. Evans SC, Frazer AL, Blossom JB, Fite PJ. Forms and functions of aggression in early childhood. J Clin Child Adolesc Psychol. 2019; 48(5): 790-798. [Link]

28. Howes C, Olenick M. Family and child care influences on toddler's compliance. Child Dev. 1986: 57(1): 202-216. [Link]

29. Lindsay AC, Greaney ML, Wallington SF, Mesa T, Salas CF. A review of early influences on physical activity and sedentary behaviors of preschool-age children in high-income countries. J Spec Pediatr Nurs. 2017; 22(3): e12182. [Link]

30.Shahim S. Relational aggression in preschool children. Iranian Journal of Psychiatry and Clinical Psychology. 2007; 13(3): 264-271. [Persian]. [Link]

31. Archer J. A strategic approach to aggression. Soc Dev. 2001; 10(2): 267-271. [Link]

32. Yoshikawa H, Weiland C, Brooks-Gunn J, Burchinal MR, Espinosa LM, Gormley WT, et al. Investing in Our future: The evidence base on preschool education. Society for Research in Child Development; 2013. [Link]

33. Cavioni V, Zanetti MA. Social-emotional learning and students' transition from kindergarten to primary school in Italy. In: Information Resources
Management Association, editor. Early childhood development: Concepts, methodologies, tools, and applications. Hershey PA: IGI Global; 2019, pp: 528547. [Link]

34. Brock LL, Curby TW. Emotional support consistency and teacher-child relationships forecast social competence and problem behaviors in prekindergarten and kindergarten. Early Educ Dev. 2014; 25(5): 661680. [Link]

35.Skibbe LE, Montroy JJ, Bowles RP, Morrison FJ. Self-regulation and the development of literacy and language achievement from preschool through second grade. Early Child Res Q. 2019; 46: 240-251. [Link]

36. Abdullah SM. Social cognitive theory: A Bandura thought review published in 1982-2012. Psikodimensia. 2019; 18(1): 85-100. [Link]

37. Malovic M, Malovic S. Parents' perspective on the quality of kindergarten. Research in Pedagogy. 2017; 7(2): 200-220. [Link]

38. Sparrow SS, Cicchetti DV. The Vineland adaptive behavior scales. In: Newmark CS, editor. Major psychological assessment instruments, Vol 2. Needham Heights, MA, US: Allyn \& Bacon; 1989, pp: 199-231. [Link]

39. Tavakkoli MA, Baghooli H, Ghamat Boland HR, Bolhari J, Birashk B. Standardizing Vineland adaptive behavior scale among iranian population. Iranian Journal of Psychiatry and Clinical Psychology. 2000; 5(4): 27-37. [Persian]. [Link]

40.Achenbach TM, Edelbrock CS. Manual for the child behavior checklist and revised child behavior profile. Burlington, VT : T.M. Achenbach; 1983, pp: 393-405. [Link]

41. Bordin IA, Rocha MM, Paula CS, Teixeira MC, Achenbach TM, Rescorla LA, et al. Child behavior checklist (CBCL), youth self-report (YSR) and teacher's report form (TRF): An overview of the development of the original and Brazilian versions. Cad Saude Publica. 2013; 29(1): 13-28. [Link]

42. Minaei A. Factorial invariance of syndromes' items of Achenbach's child behavior checklist (CBCL). Educational Psychology. 2007; 3(7): 93-116. [Persian]. [Link] 